\title{
The Role of Heterotrophic Microalgae in Waste Conversion to Biofuels and Bioproducts
}

\author{
Teresa Lopes da Silva ${ }^{1, *}$, Patrícia Moniz ${ }^{1}$, Carla Silva ${ }^{2}$ and Alberto Reis ${ }^{1}$ \\ 1 LNEG-National Laboratory for the Energy and Geology, I.P.-Bioenergy and Biorefineries Unit, \\ Estrada do Paço do Lumiar, 22, Edifício F-R/C, 1649-038 Lisboa, Portugal; patricia.moniz@lneg.pt (P.M.); \\ alberto.reis@lneg.pt (A.R.) \\ 2 Instituto Dom Luiz (IDL), Faculdade de Ciências da Universidade de Lisboa, Campo Grande, \\ 1747-016 Lisbon, Portugal; camsilva@fc.ul.pt \\ * Correspondence: teresa.lopessilva@lneg.pt; Tel.: +351-21-092-4600
}

Citation: Silva, T.L.d.; Moniz, P.; Silva, C.; Reis, A. The Role of Heterotrophic Microalgae in Waste Conversion to Biofuels and Bioproducts. Processes 2021, 9, 1090 . https://doi.org/10.3390/pr9071090

Academic Editor: José F.O. Granjo

Received: 30 April 2021

Accepted: 17 June 2021

Published: 23 June 2021

Publisher's Note: MDPI stays neutral with regard to jurisdictional claims in published maps and institutional affiliations.

Copyright: (c) 2021 by the authors. Licensee MDPI, Basel, Switzerland. This article is an open access article distributed under the terms and conditions of the Creative Commons Attribution (CC BY) license (https:// creativecommons.org/licenses/by/ $4.0 /)$.

\begin{abstract}
In the last few decades, microalgae have attracted attention from the scientific community worldwide, being considered a promising feedstock for renewable energy production, as well as for a wide range of high value-added products such as pigments and poly-unsaturated fatty acids for pharmaceutical, nutraceutical, food, and cosmetic markets. Despite the investments in microalgae biotechnology to date, the major obstacle to its wide commercialization is the high cost of microalgal biomass production and expensive product extraction steps. One way to reduce the microalgae production costs is the use of low-cost feedstock for microalgae production. Some wastes contain organic and inorganic components that may serve as nutrients for algal growth, decreasing the culture media cost and, thus, the overall process costs. Most of the research studies on microalgae waste treatment use autotrophic and mixotrophic microalgae growth. Research on heterotrophic microalgae to treat wastes is still scarce, although this cultivation mode shows several benefits over the others, such as higher organic carbon load tolerance, intracellular products production, and stability in production all year round, regardless of the location and climate. In this review article, the use of heterotrophic microalgae to simultaneously treat wastes and produce high value-added bioproducts and biofuels will be discussed, critically analyzing the most recent research done in this area so far and envisioning the use of this approach to a commercial scale in the near future.
\end{abstract}

Keywords: wastes treatment; heterotrophic microalgae; high value-added products

\section{Introduction}

Each year, the European Union generates 2.5 billion tons of waste, or five ton per person. The waste may contain large volumes of valuable materials for the EU industry, such as nutrients, paper, wood, industrial minerals, and metals. Some of these can be recycled close to $100 \%$ with no losses in quantity and quality [1]. The EU waste management policies are aimed at the reduction of the environmental and health impacts of waste and improving Europe's resource efficiency.

The long-term goal is to turn Europe into a full recycling society, avoiding waste and using unavoidable waste as a resource, wherever possible. The release of waste streams into the environment and natural waterbodies affects ecosystems, which raises serious problems for human society in terms of sustainability. Waste stream treatment aims to significantly reduce the quantity of pollutants, namely carbonaceous organic, nitrogen $(\mathrm{N})$ and phosphorus $(\mathrm{P})$ compounds, and recalcitrant compounds, prior to being discharged into the environment [2,3] as these materials, in large concentrations, may affect the equilibrium of ecosystems, fauna, and flora, and threaten human health [4].

Microalgae are considered robust and versatile microorganisms, as they can have autotrophic, mixotrophic, or heterotrophic metabolisms. Therefore, these microorganisms can be used to treat different types of waste streams, simultaneously producing valuable 
products (i.e., polyunsaturated fatty acids, pigments, proteins, animal feed, biofertilizers, and biofuels) that may be used in diverse industries, such as food, feed, pharmaceutical, nutraceutical, cosmetic, and chemical, as real biorefinery alternatives. Furthermore, this approach takes advantage of the whole or part of the microalgal biomass and the various products synthesized by the cells, therefore maximizing the value derived from the whole process, with environmental benefits [5].

Although conventional wastewater treatment systems are currently used worldwide, their application is considered an environmental problem due to the high amounts of waste sludge produced [6]. In order to reduce the environmental impact of wastewater treatment, it is therefore necessary to use processes with a substantial reduction in energy consumption and sludge production [7].

The major advantages of microalgal-based waste stream treatment are that additional pollution is not generated when the biomass is harvested, allowing efficient nutrient recycling and interesting product production [5,8-12].

Most of the published works describing biological waste treatment use autotrophic microalgae, which require light as a source of energy and carbon dioxide $\left(\mathrm{CO}_{2}\right)$, as a carbon source. Little work on using heterotrophic microalgae to treat real waste streams has been done; despite the higher biomass concentrations, growth rates and lipid productivities can be obtained, compared to autotrophic microalgae growth, because the former is grown in conventional bioreactors that are easily operated, controlled, and maintained. As a result, higher cell masses are obtained due to the higher carbon source energy density when compared to $\mathrm{CO}_{2}$. In addition, fed-batch culture strategies can be implemented to increase the microalgal biomass and products even more, resulting in the biomass harvesting costs reduction [13]. Direct air can be used, instead of previously treated flue gas, because oxygen $\left(\mathrm{O}_{2}\right)$ is consumed and $\mathrm{CO}_{2}$ generated. All these benefits lead to efficient waste treatment by heterotrophic microalgae; thus, knowledge in this field is needed. In addition, most of the published works reporting heterotrophic microalgae grown on organic substrates are limited to pure glucose, glycerol, and acetate [14]. However, heterotrophic microalgae growth on these substrates is costly. According to Wang et al. [6], the total feedstock costs can achieve up to $80 \%$ of the total process costs when using glucose as a carbon source. In this way, zero or low-cost substrates such as wastes (including wastewater and industrial byproducts and residues) should be used as a source of nutrients for heterotrophic microalgae growth, not only to reduce the overall process costs [15] but also to accomplish the EU Circular Economy Action Plan 2020, known as The European Green Deal, which is aimed at boosting the efficient use of resources by moving to a clean, circular economy, restoring biodiversity and cutting pollution [15].

This review article will focus on the use of heterotrophic microalgae to treat wastes, specifically food wastes, municipal/domestic wastewater, and glycerol derived from the biodiesel industry because these streams are suitable for heterotrophic metabolism due to their high organic carbon content. The most recent research done in this area will be critically analyzed, and the use of this approach to a commercial scale in the near future is envisioned.

\section{Autotrophic Versus Heterotrophic Mode for Microalgal Waste Stream Treatment}

Autotrophic microalgae convert solar energy into valuable biomass, incorporating nitrogen and phosphorous [16]. Due to their capacity to fix carbon dioxide $\left(\mathrm{CO}_{2}\right)$, using this compound as a carbon source, and light as the source of energy, these microorganisms contribute to greenhouse gas effect mitigation (Table 1). The use of autotrophic microalgae to treat waste streams shows other benefits, such as the consumption or biotransformation of pollutants. Organic matter degradation can be enhanced in the presence of heterotrophic bacteria because the microalgae supply additional oxygen from photosynthesis to the bacteria populations, improving their growth and metabolism, and thus COD removal from the waste stream. This approach reduces the total energy costs of direct (gassing performance) or indirect (stirring performance) oxygen supply [17]. 
Table 1. Microalgal autotrophic/heterotrophic growths.

\begin{tabular}{|c|c|c|}
\hline & Autotrophic Cultures & Heterotrophic Cultures \\
\hline Advantages & $\begin{array}{ll}- & \mathrm{CO}_{2} \text { fixation } \Rightarrow \text { GHG mitigation } \\
- & \text { Efficient } \mathrm{N} \text { and } \mathrm{P} \text { removal }\end{array}$ & $\begin{array}{ll}\text { - } & \text { Non-dependence of light and } \\
\text { season } \\
\text { - } & \text { Efficient organic carbon removal } \\
\text { - } & \text { Simpler and cheaper conventional } \\
\text { bioreactors than photobioreactors } \\
\text { - } \quad \text { High cell-density cultures } \Rightarrow \text { high } \\
\text { intracellular product } \\
\text { productivities }\end{array}$ \\
\hline Drawbacks & $\begin{array}{l}\text { - } \quad \text { Light and season dependence } \\
\text { Low cell-density cultures due to } \\
\text { light shadow } \\
\text { Photobioreactors are expensive } \\
\text { and difficult to scale-up }\end{array}$ & $\begin{array}{l}\text { - } \mathrm{CO}_{2} \text { emission } \\
\text { High contamination risk by other } \\
\text { heterotrophic microorganisms } \\
\text { - Sterilization requirement is an } \\
\text { expensive energetic step }\end{array}$ \\
\hline
\end{tabular}

However, autotrophic microalgae for waste treatment show a few bottlenecks: (i) it is only possible if $\mathrm{CO}_{2}$ is available; (ii) the microalgae growth is light-depending, requiring expensive and specific equipment design; (iii) for an efficient conversion, the waste streams are usually treated in large volumes, in photobioreactors, in which light penetration into the dense cultures is hindered due to the self-shading effect; (iv) as a result, the microalgae cell concentration in the culture is usually low, due to the inefficient light penetration aggravated by the light shading effect. Furthermore, when the wastes contain particles (which often occurs), the cells do not receive adequate light due to the high turbidity that hinders adequate light penetration. These limitations are particularly evident when autotrophic microalgae are used for primary wastewater treatments [13]. In addition, microalgae grown under autotrophic conditions usually produce low amounts of intracellular products, such as lipids and pigments, due to the low biomass concentrations and productivities. Moreover, autotrophic microalgae growth is affected by temperature and light availability; hence, this technology is not suitable in areas of high latitude, where most seasons have low temperature and fewer daylight hours.

Most of the works reporting microalgae waste treatment use a symbiotic biological system between autotrophic/mixotrophic microalgae and bacteria populations because autotrophic microalgae are inefficient in removing high COD loads. Mohsenpour et al. [7] stated that wastewater treated by algal-bacterial co-cultures efficiently removes either inorganic nitrogen or phosphorous, requiring only a single-step treatment stage, which reduces the complexity and energy of the whole treatment process. In fact, phosphorous and nitrogen are efficiently removed from the waste by autotrophic and mixotrophic microalgae, but these microorganisms are unable to remove high COD loads from high polluting wastes, such as dairy or food effluents. In such systems, heterotrophic bacteria present in the waste are essential for removing the COD and supply the $\mathrm{CO}_{2}$ required by the photoautotrophic/mixotrophic microalgae metabolism. This approach may be efficient for treating effluents and waste but usually does not allow the sustainable production of valuable microbial products because the bacteria presence reduces the final concentrations of microalgal biomass and related microalgal-based bioproducts. Generally, bacteria do not produce valuable products [18]. Therefore, the consortia autotrophic microalgae/heterotrophic bacteria, although efficient in treating effluents, is unable to treat wastes with concomitant high value-added product production.

Heterotrophic microalgae use organic compounds as carbon and energy sources to grow and do not use light as an energy source (Figure 1, Table 1). 


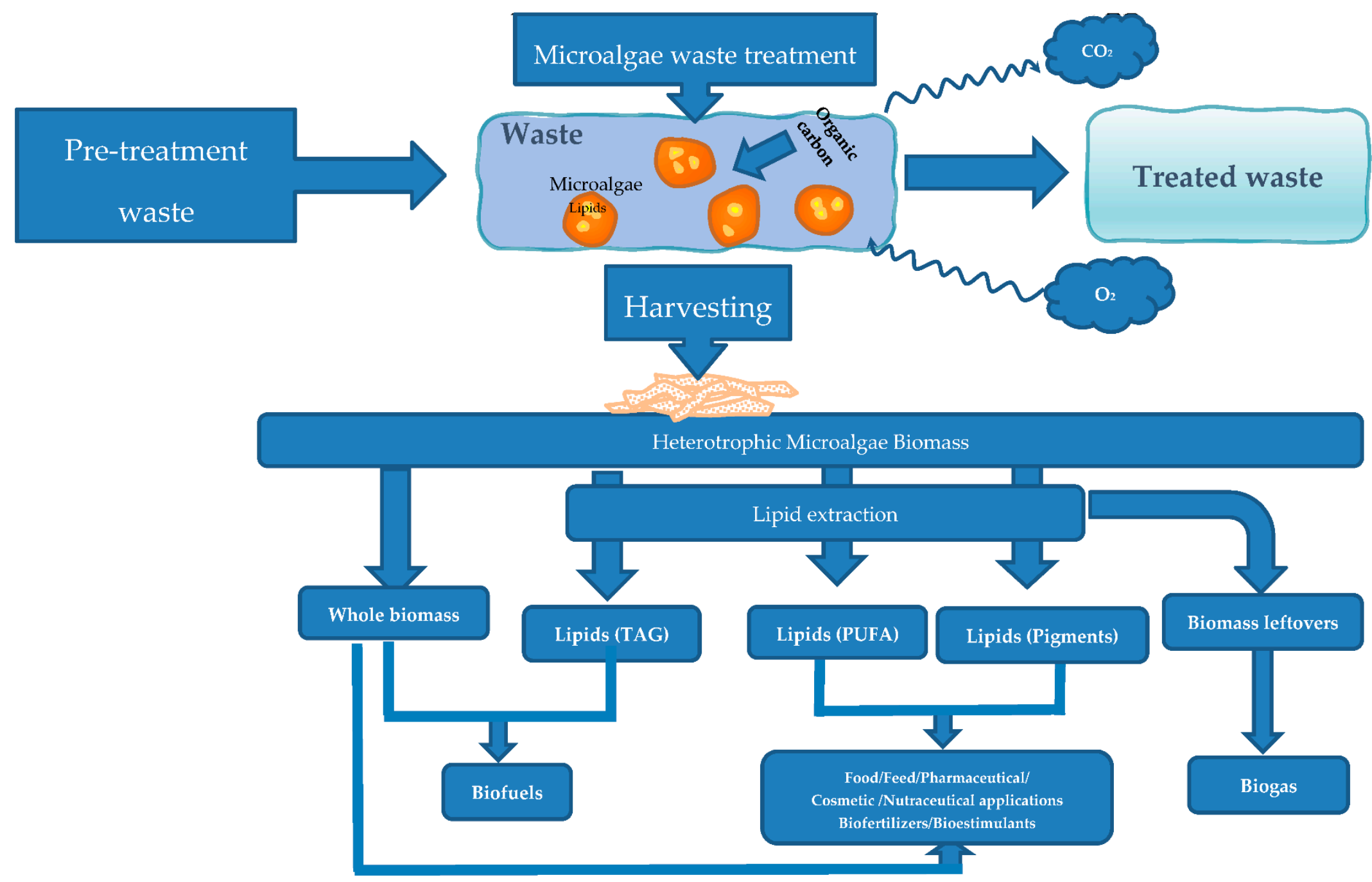

Figure 1. Heterotrophic metabolism and microalgal biomass applications. 
Indeed, these microorganisms show several benefits over the autotrophic microalgae to treat waste streams, such as: (a) they can grow in cheaper bioreactors, requiring less sophisticated equipment, and are therefore easily scaled-up; (b) they do not require light to grow, which reduces the equipment requirements and costs; (c) the cultures attain higher, denser cell concentrations and intracellular product productivities than autotrophic cultures; (d) the algal biomass composition can be tailored by changing the type of organic substrate in the medium; (e) heterotrophic microalgae can remove organic carbonaceous, nitrogen, and phosphorus compounds from the wastes more efficiently than autotrophic growth [19-21].

According to Morales-Sánchez et al. [20], cell densities in the order of $100 \mathrm{~g} / \mathrm{L}$ can be easily achieved in heterotrophic microalgal cultivations, which simplifies the biomass harvesting step. Xu et al. [22] reported an increase in lipid content of $40 \%$ in a Chlorella protothecoides culture after the cultivation mode was changed from photoautotrophic to heterotrophic. In contrast, under autotrophic conditions, the maximum cell density of microalgae that can be achieved in photobioreactors is around $5 \mathrm{~g} / \mathrm{L}$, while in outdoor open-pond or raceway-pond cultures, the cell concentration is usually lower than $0.5 \mathrm{~g} / \mathrm{L}$, which significantly increases the energy consumption of the biomass harvesting step, and thus the cost of biomass production [23]. In addition, as above referred, the heterotrophic cultivation can be carried out in conventional industrial-scale fermenters, which ensures better control over process parameters such as $\mathrm{pH}$, temperature, oxygen levels, and carbon source [13].

Substrate inhibition due to very high initial substrate concentration can be overcome by process strategies, such as fed-batch and continuous regimes; even at very high cell densities, the cell growth is not limited by self-shading of the light supply, which usually limits the photoautotrophic cultures [24].

\section{Heterotrophic Microalgae Waste Treatment}

\subsection{Heterotrophic Metabolism}

Heterotrophic microalgae use respiration to produce energy by organic substrate oxidization. The most-used carbon sources to grow heterotrophic microalgae are glucose, glycerol, and acetate (Figure 1). Glucose has been the most used organic carbon source for microalgae cultivation because it produces more energy per mole than other substrates. This monosaccharide is also abundant in sugarcane molasses and syrups that result from vegetable pulp extraction, such as carob pulp, which has been used in media formulation for heterotrophic microalgae growth $[25,26]$. Glucose oxidative assimilation involves two metabolic routes: Embden-Meyerhof (EM) and Pentose Phosphate (PP) pathways, as shown in Figure 1.

Acetate (or acetic acid) is another common carbon source used to grow heterotrophic microalgae $[25,27]$. Once inside the microalgae cells, in the cytoplasm, acetate is metabolized by acetylation of coenzyme A by acetyl-CoA synthetase (EC 6.2.1.1) in a single-step catalyzed reaction, using a single ATP molecule, to form acetyl coenzyme A (acetyl-CoA). Acetate (carried by coenzyme A) is generally metabolized through two pathways: (i) the glyoxylate cycle, to form malate through the glyoxylate cycle, and (ii) through the Tricarboxylic Acid Cycle (TCA) to form citrate in the mitochondria, which provides carbon skeletons, energy source as ATP, and energy for reduction (NADH) (Figure 2). However, acetate can be toxic for many microorganisms at high concentrations, inhibiting growth. Therefore, it is commonly used for buffering high $\mathrm{pH}$ levels in bioreactors, keeping the acetate concentration at low levels in fed-batch configurations or $\mathrm{pH}$-auxostat systems, in which $\mathrm{pH}$ is maintained constant [28].

Glycerol is another carbon source that has been used as a carbon source for heterotrophic microalgae growth $[25,29,30]$. It is a by-product from the biodiesel industry, being considered a waste product because of the associated disposal cost, and if left unattended, poses an environmental threat. Previously, only pure glycerol was used as a carbon source in microbial media formulations because the impurities present in crude glycerol 
(methanol, ethanol, salts, metals, and soaps) could inhibit microbial growth, hindering the biological conversion of crude glycerol [31,32].

However, purification of crude glycerol is expensive and burdensome; hence, the conversion of glycerol through biological routes using microorganisms is a viable way to enhance the economy of the process. When inside the cells, glycerol is firstly phosphorylated to glycerol phosphate, using ATP, and is eventually oxidized to triose phosphate. Enzymes glycerol kinase (EC 2.7.1.30), sn-glycerol-3-phosphate NAD oxidoreductase (EC 1.1.1.8), and triose-phosphate (EC: 5.3.1.1) are involved in the conversion of glycerol into glyceraldehyde-3-phosphate and glycerate, which are intermediates involved in the EMP pathway of glycolysis, to form pyruvate that enters the TCA cycle [13,21] (Figure 2).

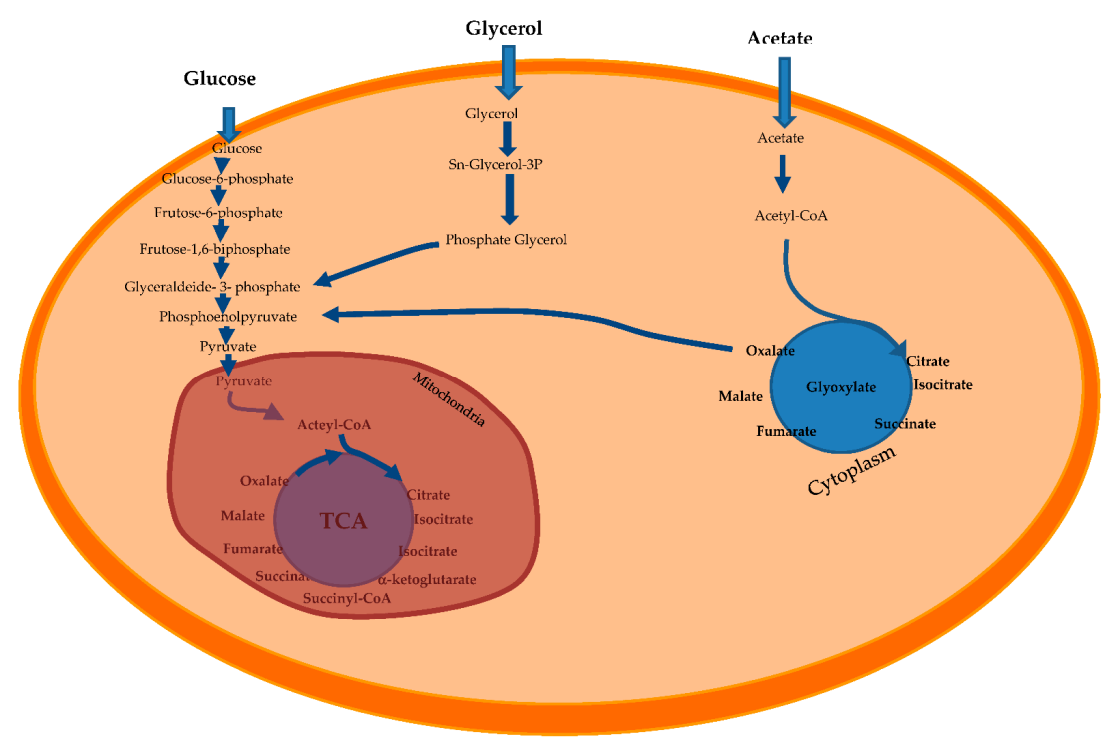

Figure 2. Carbon metabolism by heterotrophic microalgae.

\subsection{Waste Pre-Treatment Step}

Different types of waste can be converted into biofuels and high value-added products by heterotrophic microalgae. As shown in Table 2, wastes from the food industry are the most used for this purpose because they contain appreciable organic carbon amounts. Domestic, municipal, and aquaculture wastewaters have also been used. Glycerol was also used as a carbon source to grow Crypthecodinium cohnii microalga, previously distilled to remove methanol [26].

The organic carbon present in wastes is generally heterogeneous and is often in the form of compounds ranging from simple molecules, such as short-chain organic acids and peptides, to more complex compounds, such as polycyclic aromatic hydrocarbons, synthetic polymers, polysaccharides, polyphenols, proteins, lipids, large fatty acids, detergents, antibiotics, and chemical derivatives [7]. However, as unicellular organisms, microalgae can only use relatively simple molecules, such as nitrogen compounds, sugars, organic and amino acids, and several aromatic compounds [13]. Therefore, a previous waste pretreatment step is usually needed to remove particles and recover or extract the soluble nutrients (e.g., C, N, P) required for the microalgal heterotrophic metabolism, which are unavailable in the untreated waste.

Centrifugation [33,34], filtration [14,35], and decantation [36] have been used to remove solid particles from the media (Table 2). After this step, enzymatic or chemical hydrolysis is frequently used. Enzymatic hydrolysis using a commercial amylolytic enzyme was used to obtain hydrolysates rich in sugars and amino acids/peptides from restaurants and bakery food waste [37]. 
Table 2. Heterotrophic microalgae that have been reported to treat wastes.

\begin{tabular}{|c|c|c|c|c|c|c|c|}
\hline & Waste & Pre-Treatment & $\begin{array}{l}\text { System/Duration of } \\
\text { the Experiment }\end{array}$ & Nutrients Removal & Products & Observations & Reference \\
\hline $\begin{array}{l}\text { Chrypthecodinium } \\
\text { cohnii CCMP } 316\end{array}$ & Carob pulp syrup & $\begin{array}{l}\text { Carob pulp residues } \\
\text { were mixed with } \\
\text { distilled water }(1: 2 w / w) \\
\text { for the syrup extraction, } \\
\text { carried out at } 150 \\
\text { rev/min for } 6 \text { h at } 50{ }^{\circ} \mathrm{C} \text {. } \\
\text { Thereafter, the syrup was } \\
\text { pressed and squeezed, } \\
\text { and the supernatant was } \\
\text { filtered and centrifuged. } \\
\text { The liquid fraction was } \\
\text { acidified to pH } 2 \text {, in } \\
\text { order to promote } \\
\text { sucrose hydrolysis, and } \\
\text { stored at }-18^{\circ} \mathrm{C} \text {. }\end{array}$ & $\begin{array}{l}2 \text { L bioreactor, } \\
\text { fed-batch, }\end{array}$ & & $\begin{array}{l}\text { Lipids: } 9.2 \% \text { w/w } \\
\text { DHA: } 1.99 \mathrm{~g} / \mathrm{L} ; \\
45.2 \mathrm{mg} / \mathrm{g} \mathrm{DCW} \\
\text { DHA/TFA: } 48 \% \\
(w / w)\end{array}$ & & [38] \\
\hline $\begin{array}{l}\text { Schizochytrium } \\
\text { limacinum SR } 21\end{array}$ & Cull potato & $\begin{array}{l}\text { Cull potato was boiled } \\
\text { and minced and mixed } \\
\text { with } \\
\text { water in a 5-L tank with } \\
\text { agitation. } \\
\alpha \text {-amylase and } \\
\text { glucoamylase were used } \\
\text { to hydrolyze the potato } \\
\text { starch into glucose. }\end{array}$ & $\begin{array}{c}150 \mathrm{~mL} \\
\text { Erlenmeyer } / 6 \text { days }\end{array}$ & & DHA: $5.35 \mathrm{~g} / \mathrm{L}$ & $\begin{array}{l}50 \% \text { of hydrolyzed potato } \\
\text { broth in the culture } \\
\text { medium was used with } 20 \\
\text { g/L glucose } \\
\text { supplementation }\end{array}$ & [39] \\
\hline $\begin{array}{l}\text { Scenedesmus sp. and } \\
\text { Chlorella sp. }\end{array}$ & $\begin{array}{l}\text { Acid rich effluent } \\
\text { collected from a } \\
\text { bench scale anaerobic } \\
\text { sequencing batch } \\
\text { reactor (AnSBR) } \\
\text { operated with } \\
\text { composite food } \\
\text { waste }\end{array}$ & & $\begin{array}{l}250 \mathrm{~mL} \text { conical flasks } \\
\text { with } 180 \mathrm{~mL} \text { liquid } \\
\text { medium/11 days }\end{array}$ & COD: $91.4 \pm 0.6 \%$ & $\begin{array}{l}\text { Biomass: } 1.42 \mathrm{~g} / \mathrm{L} \\
\text { Lipids: } 26.4(w / w)\end{array}$ & $\begin{array}{l}\text { Microalgae cultures flasks } \\
\text { were } \\
\text { grown at a photo period of } \\
12 \mathrm{~h} \text { sunlight and } 12 \mathrm{~h} \text { dark }\end{array}$ & [40] \\
\hline
\end{tabular}


Table 2. Cont.

\begin{tabular}{|c|c|c|c|c|c|c|c|}
\hline & Waste & Pre-Treatment & $\begin{array}{l}\text { System/Duration of } \\
\text { the Experiment }\end{array}$ & Nutrients Removal & Products & Observations & Reference \\
\hline Chlorella sp. & $\begin{array}{l}\text { Lipid extracted } \\
\text { microalgae biomass } \\
\text { residues (LMBs) + } \\
\text { sugarcane molasses } \\
\text { Mixture ratio: } 1 / 4 \\
(v / v)\end{array}$ & $\begin{array}{c}\text { LMBRs: } \\
50 \text { g lyophilized LMBRs } \\
\text { dissolved in distilled } \\
\text { water were hydrolyzed } \\
\text { using cellulase, neutrase, } \\
\text { and alcalase; } \\
\text { Crude molasses: } \\
\text { Dilution with distilled } \\
\text { water (1:9); followed by } \\
\text { hydrolysis with neutrase } \\
\text { and alcalase, followed by } \\
\text { the acidic hydrolysis } \\
\text { (addition of } \mathrm{H}_{2} \mathrm{SO}_{4} 5 \mathrm{M} \text {, } \\
\text { adjusting pH to } 3.5, \text { at } \\
60^{\circ} \mathrm{C} \text { for } 1 \mathrm{~h} \text { ). }\end{array}$ & $\begin{array}{l}500 \mathrm{~mL} \text { Flasks with } \\
300 \mathrm{~mL} \text { liquid } \\
\text { medium, } 150 \mathrm{rpm}, \\
25^{\circ} \mathrm{C} / 7 \text { days }\end{array}$ & & $\begin{array}{c}\text { Biomass: } 5.6 \mathrm{~g} / \mathrm{L} \\
\text { Lipids: } 43 \%(w / w)\end{array}$ & & [41] \\
\hline $\begin{array}{c}\text { Schizochytrium } \\
\text { mangrovei }\end{array}$ & $\begin{array}{l}\text { Food waste (rice, } \\
\text { noodles, meat, } \\
\text { vegetables collected } \\
\text { from canteens) }\end{array}$ & $\begin{array}{c}\text { Food waste hydrolysis } \\
\text { using Aspergillus awamori } \\
\text { and Aspergillus oryzae } \\
\text { fungal glucoamylases, } \\
\text { proteases, and } \\
\text { phosphatases. }\end{array}$ & $\begin{array}{l}2 \mathrm{~L} \text { bioreactor } \\
\text { batch mode/7 days }\end{array}$ & & $\begin{array}{c}\text { Lipids: } 3.3 \mathrm{~g} / \mathrm{L} ; \\
16.5 \%(w / w) ; \\
\text { DHA: } 85.5 \pm \\
11.2 \mathrm{mg} / \mathrm{g} \\
\text { Lipids: } 1.050 \mathrm{~g} / \mathrm{L} ; \\
20.99 \%(w / w) \\
\text { DHA: } 0\end{array}$ & & [42] \\
\hline $\begin{array}{l}\text { Scenedesmus sp. } \\
\text { ZTY2, Scenedesmus sp. } \\
\text { ZTY3 Chlorella sp. } \\
\text { ZTY4 }\end{array}$ & Domestic wastewater & $\begin{array}{l}\text { Centrifugation followed } \\
\text { by sterilization }\end{array}$ & $\begin{array}{c}500 \text { mL shake flasks } \\
\text { /11 days }\end{array}$ & & $\begin{array}{c}\text { Lipids } \\
\text { Scenedesmus sp. } \\
\text { ZTY2: } 69.1 \%(w / w) \\
\text { Scenedesmus sp. } \\
\text { ZTY3: } 52.9 \% \text { w/w } \\
\text { Chlorella sp. ZTY4: } \\
\text { 64.4\% }(w / w) \\
\text { Biomass, } \\
\text { respectively: } \\
0.04,0.045,0.054 \mathrm{~g} / \mathrm{L}\end{array}$ & & [43] \\
\hline
\end{tabular}


Table 2. Cont.

\begin{tabular}{|c|c|c|c|c|c|c|c|}
\hline & Waste & Pre-Treatment & $\begin{array}{c}\text { System/Duration of } \\
\text { the Experiment }\end{array}$ & Nutrients Removal & Products & Observations & Reference \\
\hline $\begin{array}{l}\text { Chlorococcum sp. } \\
\text { RAP-13 }\end{array}$ & $\begin{array}{c}\text { Dairy effluent } \\
\text { supplemented with } \\
6 \% \text { biodiesel industry } \\
\text { waste glycerol }\end{array}$ & $\begin{array}{l}\text { Stored at } 4{ }^{\circ} \mathrm{C} \text { in } \\
\text { sterilized containers } \\
\text { before use }\end{array}$ & $\begin{array}{l}500 \mathrm{~mL} \text { with } 200 \mathrm{~mL} \\
\text { untreated effluent } \\
/ 15 \text { days }\end{array}$ & $\begin{array}{l}\text { COD: } 93 \% \\
\text { BOD: } 82 \%\end{array}$ & $\begin{array}{l}\text { Biomass: } 1.96 \mathrm{~g} / \mathrm{L} \\
\text { Lipids: } 42 \% w / w\end{array}$ & & [29] \\
\hline $\begin{array}{l}\text { Chrypthecodinium } \\
\text { cohnii ATCC } 30772\end{array}$ & $\begin{array}{l}\text { Rapeseed meal } \\
\text { hydrolysate + crude } \\
\text { waste molasses }\end{array}$ & $\begin{array}{c}\text { Rapeseed meal: } \\
\text { solid-state fermentation } \\
\text { using Aspergillus oryzae } \\
\text { LZ01, Penicillium } \\
\text { oxalicum J1, and } \\
\text { Neurospora crassa J2 } \\
\text { fungal strains; } \\
\text { Crude waste molasses: } \\
\text { diluted with distilled } \\
\text { water and acidified to } \\
\text { pH } 3.0, \\
\text { heated to } 100^{\circ} \mathrm{C} \text { for } 1 \mathrm{~h} \text {, } \\
\text { followed by } \\
\text { centrifugation }\end{array}$ & $\begin{array}{l}500 \text { mL-Erlenmeyers, } \\
\text { batch, } 7 \text { days }\end{array}$ & & $\begin{array}{c}\text { Lipids: } 27.3 \%(w / w) \\
(w / w \text { DCW }) ; 26.9 \mathrm{~g} / \mathrm{L} \\
\text { DHA: } 8.7 \mathrm{mg} / \mathrm{L} ; \\
\text { DHA/TFA: } 22-34 \% \\
w / w\end{array}$ & & {$[44]$} \\
\hline $\begin{array}{l}\text { Scenedesmus sp., } \\
\text { Chlamydomonas sp., } \\
\text { Chlorococcum } \\
\text { humicola, Botryococcus } \\
\text { braunii } \\
\text { Chlorella sp., } \\
\text { Chlorella sp. }\end{array}$ & $\begin{array}{l}\text { Surfactant mediated } \\
\text { municipal } \\
\text { wastewater (SMMW) }\end{array}$ & $\begin{array}{l}\text { Stored at } 4{ }^{\circ} \mathrm{C} \text { to } \\
\text { minimize } \\
\text { substrate decomposition, } \\
\text { followed by mixing } \\
\text { for } 5 \mathrm{~min} \text {, followed by a } \\
30 \mathrm{~min} \text { settling, to } \\
\text { allow the settlement of } \\
\text { excess colloidal particles }\end{array}$ & & $\begin{array}{c}\mathrm{COD}>98 \% \\
\mathrm{PO}_{4}-\mathrm{P}>98 \% \\
\mathrm{NO}_{3}-\mathrm{N}>99 \% \\
\mathrm{NH}_{4}-\mathrm{N} \sim 100 \%\end{array}$ & $\begin{array}{c}\text { Biomass: } \\
0.41-0.50 \mathrm{~g} / \mathrm{L} \\
\text { Lipids: } \\
21.5-42.0 \%(w / w)\end{array}$ & $\begin{array}{l}\text { Previous facultative } \\
\text { heterotrophic strains } \\
\text { screening for the capacity } \\
\text { to grow in SMMW }\end{array}$ & {$[36]$} \\
\hline $\begin{array}{l}\text { Chlorella pyrenoidosa } \\
\text { (NCIM 2738) }\end{array}$ & $\begin{array}{l}\text { Treated cane } \\
\text { molasses }\end{array}$ & $\begin{array}{c}\text { Dilution } 1: 1 \text { with } \\
\text { distilled water followed } \\
\text { by centrifugation at } 2000 \\
\text { rpm, } 30 \text { min. } \\
\text { The clarified liquid was } \\
\text { passed through a strong } \\
\text { acidic cation } \\
\text { exchange resin for the } \\
\text { removal of metal ions. }\end{array}$ & $\begin{array}{l}250 \mathrm{~mL} \text { flasks } \\
\text { containing } 100 \mathrm{~mL} \\
\text { liquid medium }\end{array}$ & Total sugars: $92.2 \%$ & $\begin{array}{l}\text { Biomass: } 1.2 \mathrm{~g} / \mathrm{L} \\
\text { Lipids: } 66 \%(w / w)\end{array}$ & & [34] \\
\hline
\end{tabular}


Table 2. Cont

\begin{tabular}{|c|c|c|c|c|c|c|c|}
\hline & Waste & Pre-Treatment & $\begin{array}{l}\text { System/Duration of } \\
\text { the Experiment }\end{array}$ & Nutrients Removal & Products & Observations & Reference \\
\hline $\begin{array}{c}\text { Scenedesmus obliquus, } \\
\text { Chlorella } \\
\text { protothecoides }\end{array}$ & $\begin{array}{l}\text { Cheese whey } \\
\text { permeate }\end{array}$ & Filtration $(0.2 \mu \mathrm{m})$ & $\begin{array}{c}\text { Shake flasks; } \\
\text { sequential cultivation } \\
\text { of S. obliquus and C. } \\
\text { protothe- } \\
\text { coides / } 34 \text { days }\end{array}$ & Total lactose: $62 \%$ & $\begin{array}{c}\text { Biomass } \\
\text { Scenedesmus obliquus: } \\
8 \pm 0.2 \mathrm{~g} \mathrm{~L}^{-1} \\
\text { Chlorella } \\
\text { protothecoides: } 6.2 \pm \\
0.4 \mathrm{~g} \mathrm{~L}^{-1}\end{array}$ & $\begin{array}{c}\text { S. obliquus and } C \text {. } \\
\text { protothecoides sequential } \\
\text { cultivation }\end{array}$ & [14] \\
\hline Chlorella sorokiniana & $\begin{array}{c}\text { Aquaculture } \\
\text { wastewater } \\
\text { supplemented with } \\
400 \mathrm{mg} / \mathrm{L} \mathrm{NaNO}_{3}\end{array}$ & $\begin{array}{l}\text { Filtration using glass } \\
\text { fiber filter papers }\end{array}$ & $\begin{array}{l}1 \text { L Shake flasks } \\
\text { containing } \\
500 \mathrm{~mL} / 7 \text { days }\end{array}$ & $\begin{array}{c}\text { COD: } 71.9 \% \\
\mathrm{PO}_{4}-\mathrm{P}: 73.6 \% \\
\mathrm{NO}_{3}-\mathrm{N}: 84.5 \% \\
\mathrm{NH}_{4}-\mathrm{N}: 75.6 \%\end{array}$ & $\begin{array}{c}\text { Biomass: } 3.5 \mathrm{~g} / \mathrm{L} \\
\text { Lipids: } 30.2 \%(w / w) \\
\text { Carbohydrates: } \\
\text { 34.7\% }(w / w) \\
\text { Proteins: } 28.4 \%(w / w)\end{array}$ & & [35] \\
\hline $\begin{array}{l}\text { Crypthecodinium } \\
\text { cohnii CCMP } 316\end{array}$ & $\begin{array}{c}\text { Cheese Whey + Corn } \\
\text { Steep Liquor }\end{array}$ & & 250 mL-Erlenmeyers, & & $\begin{array}{c}\text { Lipids: } 28.7 \%(w / w \\
\text { DCW) } \\
\text { DHA/TFA: } 8.5-27 \% \\
w / w\end{array}$ & & [30] \\
\hline $\begin{array}{l}\text { Galdieria sulphuraria } \\
074 \mathrm{G}\end{array}$ & $\begin{array}{l}\text { Food waste from } \\
\text { restaurants } \\
\text { and bakeries }\end{array}$ & $\begin{array}{c}\text { Autoclaving for } \\
30 \text { min at } \\
121^{\circ} \mathrm{C} \text {, followed by } \\
\text { enzymatic hydrolysis } \\
\text { for } 24 \mathrm{~h} \text { at } 50^{\circ} \mathrm{C} \\
\text { and } \mathrm{pH} 4.5 \text { to produce a } \\
\text { hydrolysate rich in } \\
\text { sugars and amino } \\
\text { acids / peptides }\end{array}$ & $\begin{array}{c}500 \mathrm{~mL} \text { conical } \\
\text { flasks containing } \\
150 \mathrm{~mL} \text { of liquid } \\
\text { medium }\end{array}$ & & $\begin{array}{l}\text { Phycocyanin: } \\
20-22 \mathrm{mg} / \mathrm{g}\end{array}$ & & [37] \\
\hline $\begin{array}{l}\text { Schizochytrium sp. } \\
\text { BCRC } 33482\end{array}$ & $\begin{array}{l}\text { Sugarcane bagasse } \\
\text { with } 40 \mathrm{~g} / \mathrm{L} \text { glucose }\end{array}$ & $\begin{array}{l}\text { Alkali followed by } \\
\text { phosphoric acid } \\
\text { treatment, followed by } \\
\text { enzymatic hydrolysis } \\
\text { (cellulase) }\end{array}$ & $\begin{array}{l}250 \text { mL Flasks with } \\
50 \text { mL liquid } \\
\text { medium/ } \\
72 \mathrm{~h} \text { for the } \\
\text { pre-treatment step: } \\
120 \mathrm{~h} \text { for the } \\
\text { microalgae } \\
\text { cultivation }\end{array}$ & & $\begin{array}{l}\text { Biomass: } 10.5 \mathrm{~g} / \mathrm{L} \\
\text { Lipids: } 45.2 \%(w / w)\end{array}$ & & {$[45]$} \\
\hline
\end{tabular}


Table 2. Cont

\begin{tabular}{|c|c|c|c|c|c|c|c|}
\hline & Waste & Pre-Treatment & $\begin{array}{l}\text { System/Duration of } \\
\text { the Experiment }\end{array}$ & Nutrients Removal & Products & Observations & Reference \\
\hline $\begin{array}{l}\text { Crypthecodinium } \\
\text { cohnii ATCC } 30772\end{array}$ & $\begin{array}{c}\text { Sugarcane molasses } \\
\text { and distilled crude } \\
\text { glycerol }\end{array}$ & $\begin{array}{l}\text { Sugarcane molasses: } \\
\text { hydrolysis by pH drop to } \\
3 \text { with } \mathrm{HCl} \text {; storage at } 50 \\
{ }^{\circ} \mathrm{C} \text { for } 24 \mathrm{~h} \text {; thereafter, } \\
\text { the } \mathrm{pH} \text { was raised to } 6.5 \\
\text { using } \mathrm{NaOH} 50 \%(w / w) \\
\text { Crude glycerol } \\
\text { previously distilled to } \\
\text { remove methanol }\end{array}$ & $\begin{array}{l}500 \mathrm{~mL} \text { shake flasks } \\
\text { with } 200 \mathrm{~mL} \text { liquid } \\
\text { medium/192 h }\end{array}$ & $\begin{array}{c}\text { Molasses: } \\
\text { Glucose: } 100 \% \\
\text { Fructose: } 0 \% \\
\text { Crude Glycerol: } \\
\text { 100\% }\end{array}$ & $\begin{array}{c}\text { Sugarcane molasses: } \\
\text { Lipids: } 11.2 \%(w / w) \\
\text { DHA 5.5 mg/g DCW } \\
\text { DHA/TFA: } 49.6 \% \\
(w / w) \\
\text { Crude Glycerol: } \\
\text { Lipids: } 14.7 \%(w / w) \\
\text { DHA: } 6.6 \mathrm{mg} / \mathrm{g} \\
\text { DCW } \\
\text { DHA/TFA: } 44.7 \% \\
(w / w)\end{array}$ & & [25] \\
\hline
\end{tabular}


Cellulase, neutralase, and alcalase enzymes were used to promote de-oiled Chlorella biomass residue hydrolysis; the resulting hydrolysate, mixed with hydrolyzed molasses, was used as a substrate for Cholorella heterotrophic microalgae growth for lipid production [41]. Pleissner et al. [42] used the inocula of Aspergillus awamori and Aspergillus oryzae as a source of fungal glucoamylases, proteases, and phosphatases to hydrolysate food wastes, reporting $85 \%, 40 \%$, and $100 \%$ of carbohydrates, total nitrogen, and phosphorous yield recovery, respectively. Fungal strains (Aspergillus oryzae, LZ01; Penicillium oxalicum, $\mathrm{J} 1$; and Neurospora crassa, J2) were also used as a source of enzymes to pre-treat rapeseed meal (RSM) (Table 2). In fact, according to these authors, fungal pre-treatment is preferable to other treatments such as chemical or commercial enzymes because the former not only increased the release of nitrogen but also promoted the degradation of toxicants in meal, preventing further microalgae growth inhibition.

Nguyen et al. [46] dried and ground sugarcane bagasse to small particles $(<0.25 \mathrm{~mm})$ to ensure that the substrate had a high surface area before the hydrolysis step. An alkali followed by phosphoric acid treatment was used to remove lignin and enhance xylose release because delignification enhances the pore size of the lignocellulosic biomass due to the removal of lignin, hemicellulose, and unknown substances, thus increasing the digestibility of the cellulosic substrate for the subsequent enzymatic hydrolysis. An enzymatic hydrolysis with cellulose was used to produce a glucose and xylose rich sugarcane bagasse hydrolysate, with $54.7 \%$ and $12.5 \%$ recovery yield, respectively (Table 2 ).

Other wastes require the extraction of nutrients. The carob tree (Ceratonia siliqua L.) is a leguminous plant that has been widely cultivated in Mediterranean countries for years. The seeds of carob (10\% of the fruit dry weight) produce $12 \%$ of the world market of gum and are widely used in the food industry for candies and cakes. The pulp, which consists of $90 \%$ of the fruit dry weight, is a food industry by-product, which contains a high content of sugar (sucrose, glucose, and fructose) and tannins, and has a low content of protein and fat, which limits its application as animal feed. The sugars were extracted by Mendes et al. [39] for docosahexaenoic acid production (DHA, a compound that has many applications in the pharmaceutical, nutraceutical, and food industries due to its well-known benefits on human health) (Table 2), using the marine heterotrophic microalgae Chrypthecodinium cohniii. An additional step to hydrolyze sucrose to glucose and fructose was carried out by acidifying the carob pulp syrup to $\mathrm{pH} 2$.

Sugarcane molasses is an important by-product from sugarcane refining factories, being used as a source of readily fermentable sugars. It contains approximately $50 \%(w / w)$ of total sugars (mainly sucrose, glucose, and fructose) and water, with a low concentration of crude protein and fat, heavy metals, vitamins, and other nutrients.

Gong et al. [44] used crude waste molasses to produce DHA, using the microalga strain C. cohnii, ATCC 30772. The waste molasses was previously acidified to $\mathrm{pH} 3$ and heated to $100{ }^{\circ} \mathrm{C}$, followed by centrifugation to remove particles. Taborda et al. [25] also used sugarcane molasses to produce DHA from C. cohnii, ATCC 30772, having previously hydrolyzed the molasses by acidification, followed by storage at $50^{\circ} \mathrm{C}$ for $24 \mathrm{~h}$.

Other procedures are also required when wastes contain toxic materials, such as recalcitrant compounds and heavy metals, which may inhibit the microalgae growth. The simplest and cheapest way to reduce the toxic concentrations in the wastes consists of diluting them, as Chi et al. [40] have reported, using 50\% diluted hydrolyzed potato broth (HPB) in the medium to grow Schizochytrium limacinum, SR 21, for DHA production. However, some nutrients, essential to microalgae heterotrophic metabolism, are also diluted, decreasing their availability in the culture medium, thus reducing the process yield. In these cases, it may be necessary to supplement the medium with the missing nutrients, as Chi et al. [39] have done, by adding $20 \mathrm{~g} / \mathrm{L}$ glucose to the $50 \%$ diluted HPB.

Other approaches can be used to remove toxic compounds from the wastes or reduce their concentrations. Gaurav et al. [34] have used a strong acidic cation exchange resin to remove metal ions from treated cane molasses, before using it to grow Chlorella pyrenoidosa, NCIM 2738, for lipid production. Taborda et al. [25] have used, for the first time, crude 
glycerol from the biodiesel industry, previously distilled, in order to remove the methanol, a transesterification reaction by-product resulting from the biodiesel production process, which is known to inhibit microbial growth (Table 2).

The use of these pre-treatments to make nutrients available for heterotrophic microalgae metabolism, or to remove toxic from waste, increases the overall process costs. In this way, the overall process is only economically sustainable if other profits are obtained, such as high value-added microalgal products produced together with the waste treatment, which should be evaluated before the process scale-up.

\subsection{Strains}

The selection of heterotrophic microalgae strains for waste treatment should consider a few criteria, such as: (i) robustness to the adverse stress conditions that exists in the wastes; (ii) versatility and capacity to grow on different types of wastes; (iii) capacity to produce high cell dense suspensions, simultaneously producing valuable intracellular compounds, in order to improve the process profit; (iv) the cell walls must resist hydrodynamic and mechanical shear, which are present in the large bioreactors used to grow heterotrophic microorganisms.

Only a few microalgae strains are able to grow under heterotrophic conditions. According to Table 2, the most used genera that can grow heterotrophically on wastes are Chlorella and Scenedesmus, being the microalgae considered the most versatile and robust to the adverse conditions that exist in a wide range of wastes, being able to produce significant amounts of intracellular lipids during the growth on the wastes.

The obligatory heterotrophic microalgae Chrypthecodinium cohnii, Schizochytrium limacinum, and Schizochytrium mangrovei can grow on different types of wastes containing high COD contents, producing not only appreciable amounts of lipids but also valuable polyunsaturated fatty acids, such as DHA. Galdieria sulphuraria was used to treat food waste from restaurants and bakeries to produce phycocyanin, a valuable pigment widely used as a food colorant [38].

\subsection{Media Supplementation}

Wastes are usually composed of different types of complex materials [46], which often do not fulfil the required nutrients that allow heterotrophic microalgae growth. For instance, after microbial secondary treatment, most municipal and domestic wastewater still contains large amounts of organic carbon, which is suitable for bacterial growth but not for microalgae [13] because the former can degrade these compounds but the latter cannot. In other cases, after the secondary treatment, the effluents contain low amounts of dissolved organic carbon that do not allow massive heterotrophic growth.

As mentioned above, microalgae can only uptake relatively simple molecules, such as nitrogen compounds, sugars, organic and amino acids, and several aromatic compounds. Therefore, nutritional supplements required for heterotrophic microalgae metabolism must be added to the effluents and wastes used as media culture. Table 2 shows that different organic carbon sources have been added to different types of wastes. Glucose $(20 \mathrm{~g} / \mathrm{L})$ has been added as organic carbon to cull potato wastes [39] and sugarcane bagasse ( $40 \mathrm{~g} / \mathrm{L})$ [45]. Different types of wastes have been mixed to grow heterotrophic microalgae. Sabeela and Sukumaran (2015) [29] supplemented dairy effluent with 6\% biodiesel industry waste glycerol to grow Chlorococcum sp., RAP-13, for lipid production, and Gong et al. [44] mixed diluted rapeseed meal hydrolysate $(7 \% v / v)$ with $9 \%$ crude waste molasses to grow Chrypthecdnium cohnii, ATCC 30772, for DHA production. According to the authors, this approach allowed the conversion of two or more wastes with low market value into valuable microbial products, with obvious environmental and economic benefits. The addition of sodium nitrate $(400 \mathrm{mg} / \mathrm{L})$ improved Chlorella sorokiniana biomass growth on aquaculture wastewater as well as the productivities of lipid, carbohydrate, and protein [35]. 
The addition of supplements may also enhance the nutrient/toxics removal efficiency. Perez-Garcia et al. [13] reported that C. vulgaris heterotrophic growth on secondary wastewater required the addition of an organic carbon source. Several carbon sources were tested and allowed C. vulgaris heterotrophic growth, but acetate and glucose were the most efficient supplements that led to the highest ammonium heterotrophic removal rate. The authors concluded that heterotrophic microalgae growth has a higher potential than autotrophic growth to produce denser microalgal cultures because the $C$. vulgaris population densities, under heterotrophic conditions, were one order of magnitude higher than those under autotrophic culturing. Moreover, ammonium removal efficiency under heterotrophic culturing was similar to autotrophic cultivation.

\subsection{Microalgae Heterotrophic Wastewater Treatment Efficiency}

From Table 2, it can be seen that high COD removal percentages (70-99\%) have been reported by several authors using heterotrophic microalgae to treat different types of wastes.

Even a waste containing high COD loads, such as dairy effluents, as reported by Sabeela and Sukumaran [29], was successfully treated by the microalga Chlorococcum sp. under heterotrophic conditions, with $93 \%$ COD and $82 \%$ BOD removals. A removal of $62 \%$ of lactose was observed by Girard et al. [14] after a sequential cultivation of the microalgae Scenedesmus obliquus and Chlorella protothecoides grown on whey permeate (obtained during the whey protein isolation, after an ultrafiltration step). The authors reported that glucose and galactose resulting from the previous extracellular lactose hydrolysis step performed by S. obliquus were completely consumed by C. protothecoides.

Wastes containing potential inhibitors were successfully treated by heterotrophic microalgae. Scenedesmus sp. and Chlorella sp. were able to remove $91.4 \%$ of COD from an acid-rich effluent collected from an anaerobic sequential batch reactor [24]. Hena et al. [36] reported 98\%, 98\%, 99\%, and 100\% COD, PO4-P, NO3-N, and NH4-N removal, respectively, when several microalgae species were grown on surfactant mediated wastewater.

Crude glycerol was completely consumed by C. cohnii, ATCC 30772, when used as the organic carbon source in a synthetic medium [25]. However, when hydrolyzed sugarcane molasses were used as the carbon source, glucose was entirely consumed by this microalga, but fructose was not. The same results were reported by Mendes et al. [26], using the strain C. cohnnii, CCMP31, grown on carob pulp syrup.

As already stated, some wastes do not contain the adequate nutrient proportion to allow heterotrophic microalgae growth, and thus do not provide an efficient nutrient removal treatment. As mentioned above, Perez-Garcia et al. [13] reported that the ammonium heterotrophic uptake by Chlorella vulgaris grown on municipal wastewater was enhanced by adding sodium acetate or glucose.

\section{Microalgal Products Obtained from Heterotrophic Growth}

\subsection{Products Extraction}

So far, the most common products extracted from heterotrophic microalgal biomass are lipids because these microorganisms usually contain high amounts of intracellular oils with high proportions of high value-added lipids, such as poly-unsaturated fatty acids (PUFA), but low protein and carbohydrates contents [47].

After the microalgae fermentation, the biomass must be separated from the liquid culture by filtration, centrifugation, or by using rotary vacuum filtration. The supernatant can be used to produce biogas, avoiding its discharge into water bodies. Before the product extraction, the microalgae cells must be dried to obtain a free water microalgal biomass, which can be stored for long time periods, without degradation, using spray drying or a freeze dryer. In this step, care must be taken because the microalgal biomass should not be exposed to temperatures higher than $50{ }^{\circ} \mathrm{C}$ and intense light, as the intracellular lipids, particularly PUFA, are heat and light sensitive, being readily oxidized due to the presence of double bonds in the fatty acid chains when exposed to such conditions [5]. 
Afterwards, the microalgae cells must be disrupted to facilitate the next extraction step. A variety of methods can be used to disrupt the microalgae cells, such as solvent extraction, ionic liquids, direct saponification, high-pressure homogenization, hydrodynamic cavitation, ultrasound/microwave/pulsed electronic field and ozone treatments, and hydrolytic enzymes, followed by extraction with solvent [48]. Nevertheless, solvent extraction is the most used, with the mixtures chloroform-methanol, hexane, and hexane-isopropanol being the most used solvents [5].

The heterotrophic microalgal oil can be further fractioned into different fractions with different usages. PUFA can be separated from saturated/monounsaturated fatty acids using winterization and/or urea complexation techniques. In this way, PUFA enriched fraction can be used for pharmaceutical/food/feed purposes, while the remained fraction, composed of saturated/monounsaturated fatty acids, can be further converted into biodiesel. In this way, all the microalgal oil fractions are valorized $[5,26,48]$.

Additional purification steps are needed if the microalgal extracted lipids are used for pharmaceutical/food/feed purposes. Supercritical fluid extraction has been used to concentrate docosahexaenoic acid (DHA, 22:6w3) in C. cohnii oil [49]. PUFA enriched fractions can also be obtained using lipase enzymatic reactions, producing different forms and compositions of PUFAs in triglycerides, phospholipids, other fatty acid esters, and free fatty acids [50].

\subsection{Microalgal Products}

Research to improve heterotrophic microalgae species to grow in high-density cultures, producing target products in significant amounts, has been carried out over the last few decades [51], the fed-batch heterotrophic microalgae cultures being those that achieved higher biomass and lipid productivities, because high carbon amounts can be added to the culture, without substrate inhibition [27,50-54]. According to Lowrey et al. [51], a key aspect to reduce the heterotrophic microalgae cultivation process costs is the search for alternative low-cost carbon sources that allow high biomass and product productivities, replacing expensive organic carbon sources such as glucose.

According to Table 2, various heterotrophic microalgae species that can grow on wastes are potential producers of commercially attractive products. These include lipids that may have different applications to PUFA and pigments (phycocyanin), both with applications in pharmaceutical, nutraceutical, cosmetic, and food industries. Moreover, the saponifiable lipid fraction (triacylglycerols) can be converted into biodiesel, as mentioned above (Figure 1).

From the references shown in Table 2, the heterotrophic microalgal lipid content varied between $9.2 \%$ and $69.1 \%(w / w)$, depending on the species, strain, culture conditions, and media formulation. The highest lipid content (79.2\%) was observed for Chlorella sp., ZTY4, heterotrophic growth on domestic wastewater [43].

The heterotrophic microalgae Schizochytrium mangrovei, Schizochytrium limacinum, and Crypthecodinium cohnii can use wastes to produce considerable amounts of DHA (Table 2). This compound is a long-chain fatty acid with well-known benefits for human health in the treatment of many diseases such as cancer, atherosclerosis, rheumatoid arthritis, Alzheimer's, and psoriasis. DHA is an essential $\omega-3$ PUFA of the human brain and nervous system, playing a crucial role in infant brain development. Several reports claim that many commercial formula-fed infants contain lower levels of DHA and arachidonic acid (ARA, 20:4w6) compared to breast-fed infants, thus they require the addition of DHA. As a result, in the last few decades, the global microalgae-based DHA market has increased, due to increasing public awareness about healthcare and chronic diseases and the public preference for natural sources, such as microalgae. DSM enterprise, a major worldwide DHA producer, commercializes microalgal oil rich in DHA obtained from the heterotrophic microalga Schizochytrium sp., sold as Life'sTM OMEGA, Life's DHATM products. DHASCO, and oil rich in DHA, used in the food industry is also produced by DSM, and is obtained from C. cohnii microalga. Solazyme Bunge Renewable Oils 
(SB oils), based in Brazil, uses sugarcane to produce Schizochytrium microalgae, which is commercialized as a whole algal biomass and used in the aquaculture feed industry, such as in the AlgaPrime DHA product. The facility uses sugarcane waste as an energy supply for the process [5].

According to Oliver et al. [55], glucose is the most used carbon source for $\omega-3$ PUFA production, contributing to around $80 \%$ of total cultivation cost, which is a major drawback of DHA heterotrophic production from an economic point of view. Although DHA heterotrophic production is being carried out at a commercial scale by several companies, the high economic cost and environmental impact of glucose usage as a carbon source imply that $\omega-3$ PUFA high-quality production should be carried out in cheaper ways, using cheaper carbon sources. According to Table 1, C. cohnii can produce considerable amounts of DHA when grown on wastes such as carob pulp syrup $(45.2 \mathrm{mg} / \mathrm{g})$ [38], rapeseed meal + crude waste molasses [44], cheese whey + corn steep liquor $(5 \mathrm{mg} / \mathrm{g})$ [30], and sugarcane molasses and crude glycerol (5.5 mg/g and $6.6 \mathrm{mg} / \mathrm{g}$, respectively) [24]. The microalga Schizochytrium has also been grown on food waste to produce $85.5 \mathrm{mg}$ DHA /g [42].

The pigment phycocyanin has been used as a fluorescent marker in clinical diagnostic and as food and cosmetic dye commercially produced by autotrophic microalgae. Under these conditions, it may be difficult to achieve high cell densities due to the shelf-shading effect, particularly at a larger scale, because surface area and culture volume ratio decreases, resulting in longer light paths inside the culture and darkness, which both hinder cell growth. Sloth et al. [37] have used bakery and restaurant food waste to produce phycocyanin using the microalga Galdieria sulphuraria under heterotrophic and mixotrophic conditions and reported that this microalga accumulated $10-30 \mathrm{mg} / \mathrm{g}$ DCW of phycocyanin under carbon limiting conditions.

The whole biomass can be used as feed, as mentioned above, if its composition fits this application. Alternatively, it may be used as biofertilizers or biostimulants (Figure 1). Hydrothermal liquefaction (HTL) allows the thermochemical conversion of wet whole microalgal biomass into a liquid energy carrier called 'bio-oil' or 'biocrude', which may be used as fuel. The microalgal biomass leftovers can be used as a substrate to produce biogas in an anaerobic digester [56] (Figure 1).

\section{Heterotrophic Microalgae Waste Treatment Process Monitoring}

Studies reporting heterotrophic microalgae growing on wastes to produce biofuels and high value-added products, with the simultaneous waste treatment, have been published (Table 2). Most of these works used conventional microbiological methods to monitor the microalgal cultivations (growth and intracellular products), such as optical density, which only provide average data, not giving any information on individual cell status. Other methods for cell growth detection, such as dry cell weight or serial dilution methods, present a few limitations, as the results are usually only available a period after the sample is taken, frequently when the process is over, too late to change the process control strategy [57].

However, despite several wastes being used as culture media as they contain nutrients that allow microbial growth, they may also contain inhibitor compounds, as mentioned above, such as antibiotics, chemicals, and heavy metals that are toxic for the microalgae cells and affect their metabolic activity. In particular, contaminants of emerging concern (CECs) such as pharmaceuticals, personal care products (PCPs), nanomaterials, and perfluorinated compounds have raised increasing public concerns because they are harmful to human health and ecosystems, causing endocrine disruption, chronic eco-toxicity, encouragement of antibiotic resistance, and uptake into the food chain [58]. Many CECs (especially personal care products) enter wastewater through domestic use and discharge and, for many pharmaceutical compounds, via feces and urine, after medicinal use. Therefore, wastewater is a major release point of CECs into the environment. These compounds may affect the microorganisms, specifically heterotrophic microalgae, used to treat these effluents. 
Lopes da Silva and Reis [57] described the inhibitor compounds present in potential wastes that may be used for heterotrophic growth. As previously referred, some wastes require a pre-treatment step before being used as culture media for microbial growth in order to release monomeric sugars that will be used by the microorganisms [37,42]. However, the pre-treatment step usually releases inhibitors that may affect the cell metabolism, thus reducing the process performance and yield.

In order to understand the effect of all these inhibitors on microbial cell physiology, it is essential to monitor, near real-time, the cell physiological status during the waste treatment process development. Moreover, a few heterotrophic microalgae, particularly dinoflagellates (such as Crypthecodinium cohnii), are negatively affected by the shear stress present in turbulent environments. Under high shear stress levels, the microalgae flagella were damaged [59], and the cell cycle was arrested at the G1 phase [60].

Multi-parameter flow cytometry (FC) is an advanced technique for bioprocess monitoring that gives near real-time (at-line) information on several cell functions and compartments at the individual cell level. This technique is ideal for assessing the microalgae cell stress response to adverse environmental conditions, such as those present in the wastes and mechanical bioreactors. An understanding of the microalgal cell response will allow the development of more tolerant microalgal strains to these environments, as well as more efficient bioprocess control strategies. As at-line information is available, this technique also allows changing the control strategy during the time course of the bioprocess by changing the operating conditions to achieve the highest product yields and optimal process performance.

In addition, FC also allows microalgal intracellular products at-line quantification, such as lipids and carotenoids. The addition of specific fluorescent dyes, such as Nile Red and BODYPI, to microalgae cells, in association with flow cytometric analysis, allows for atline microalgal intracellular lipid quantification, avoiding the time-consuming gravimetric techniques for lipid quantification, which involves high toxic organic solvent volumes. The use of flow cytometry for at-line carotenoid content evaluation in autotrophic microalgae cells based on the autofluorescence cells has also been reported [61], using the same protocols for heterotrophic microalgae, with adjustments if necessary. Therefore, the at-line intracellular product content information allows the microalgal biomass harvesting at the highest product productivities.

Despite the benefits, the application of FC to bioprocesses involving low-cost waste conversion by heterotrophic microalgae is still rare because the equipment is expensive and requires specialized training. Lopes da Silva and Reis [57] published a detailed description of the effects of the most known inhibitors present in low-cost feedstock on the microorganisms, highlighting the benefits of using FC to monitor such processes.

\section{Drawbacks and Bottlenecks}

The production of carbon dioxide from the respiration of organic carbon during heterotrophic growth is a drawback of the heterotrophic microalgae metabolism, contrarily to the autotrophic microalgae metabolism, which indubitably contributes to greenhouse effect mitigation. However, symbiotic heterotrophic/autotrophic microalgae consortia may be used to treat effluents. When heterotrophic and autotrophic microalgae grow in mixed cultures, the complementary nutritional requirements of each microorganism may reduce the $\mathrm{CO}_{2}$ produced by the heterotrophic microalgae because they consume $\mathrm{O}_{2}$ and produce $\mathrm{CO}_{2}$, which in turn is consumed by autotrophic microalgae that consume $\mathrm{CO}_{2}$ and produce $\mathrm{O}_{2}$, up-taken by the heterotrophic microalgae [62].

The presence of high organic compound loads in the wastes used as culture media to grow heterotrophic microalgae increases the risk for contamination by competitive heterotrophic bacteria and fungi, compromising the quality of the process and products if good laboratory practice is not followed [63]. For this reason, heterotrophic microalgae growth requires media sterilization, or, at least, sanitation, an energetic requirement that can account for $20-30 \%$ of the total production process costs. This cost may be compensated 
if high value-added products are produced by the heterotrophic microalgae due to their high market price.

One possible approach to overcome the sterilization step consists of using extremophile heterotrophic microalgae that can grow at extreme $\mathrm{pH}$, temperature, or salinity, significantly reducing or preventing competitive microbial growth [21]. The red extremophile alga Galdieria sulphuraria can grow photoautotrophically, heterotrophically, and mixotrophically and can utilize more than 50 different carbon sources such as sugars and sugar alcohols such as glycerol and amino acids. This versatility makes this microalga ideal for heterotrophic cultivation on non-sterile organic waste hydrolysate. Another possibility of reducing the heterotrophic microalgae cultivation contamination risk consists of adding antibiotics such as chloramphenicol, penicillin, and streptomycin to the media.

\section{Heterotrophic/Autotrophic Microalgae Waste Treatment Economic Evaluation}

So far, there are no industrial plants to treat waste streams using heterotrophic microalgae. The published studies using this approach were carried out at bench-scale. Nevertheless, according to Yang et al. [64], heterotrophic cultivation can be much more beneficial than photoautotrophic cultivation from an economic perspective. The input energy to ATP conversion ratio is higher for heterotrophic cultivation (18\% of the energy obtained can be converted to ATP, while only $10 \%$ is converted under photoautotrophic conditions). Similar observations were made by Behrens [65], who calculated the conversion efficiency of input energy in the form of electricity to ATP and NADPH and concluded that heterotrophic cultivation is economically more advantageous than photoautotrophic cultivation; the cost per kg of dry biomass for heterotrophic cultivation was calculated as US $\$ 2$, while for photoautotrophic cultivation it was about US\$11 [65]. Compared to microalgae autotrophic cultivation, which depends on light intensity, heterotrophic cultivation could decrease the land area needed and water evaporation significantly. In addition, Orfield et al. [66] demonstrated that the heterotrophic microalgae cultivation mode attained the highest net energy ratio (NER) among a study that compared the three microalgae cultivation modes autotrophic, heterotrophic, and mixotrophic. Because heterotrophic microalgae cultivations attain higher cell densities that are obtained under axenic conditions, they are adequate for producing high-quality bioactive compounds such as pharmaceuticals [67].

Techno-economic assessment (TEA) is the most recognized methodology to analyze a certain system cost and has embedded economic indicators such as CAPital EXpenditures (CAPEX), OPErational EXpenditures (OPEX), Net Present Value (NPV), and Internal Rate of Return (IRR). Regarding the TEA of heterotrophic microalgae use to treat waste streams, the query ALL (waste AND heterotrophic AND microalgae) and entitle ("economic assessment"), excluding patents and citations, retrieved 21 publications on the Google Scholar platform, and 4 publications in the Scopus database, as at 20.03.2021.

Within this universe, the authors identified a total of 8 publications, of which, 1 focussed on TEA uncertainty systematization needs in heterotrophic systems [68]; 1 focussed on the model for TEA in VFA-volatile fatty acids used as a low-cost carbon source to obtain biodiesel replicable from heterotrophic microalgae [69]; 1 focussed on nutrient recycling on heterotrophic systems [51], 1 focussed on liquid waste streams (Table 3) as a carbon source for heterotrophic microalgae; and 3 focussed on organic solid waste streams as a carbon source of heterotrophic microalgae (Table 3). The bioreactor is identified as the most costly equipment of scaled-up facilities. In terms of materials consumed, the carbon source is usually the bottleneck, as well as some input materials. The most expensive carbon source is glucose. Its cost in international market price is around $\$ 500 /$ ton, as of 2010 [69]. The price of food wastes and other agricultural wastes (rice straw) in Korea ranges from $\$ 50$ to $\$ 130 /$ ton, so it is considered a potential low-cost carbon source. 
Table 3. Summary of TEA studies focused on heterotrophic cultures.

\begin{tabular}{|c|c|c|c|c|}
\hline Carbon Source & System & TEA Method & Conclusions & Reference \\
\hline Food waste & $\begin{array}{c}\text { Batch; Chlorella } \\
\text { protothecoides in } \\
\text { heterotrophic cultures } \\
\text { (max } 48.7 \% \text { lipid content; } \\
\text { max } 0.187 \text { g/g yield) } \\
\text { Product: biodiesel }\end{array}$ & $\begin{array}{c}\text { OPEX w/ carbon source cost } \\
\text { (30\$/ton), NH4Cl } \$ 150 / \text { ton, } \\
\text { utilities cost of } \$ 0.035 / \mathrm{kg} \\
\left(0.1 \$ / \mathrm{kWh}^{-1}\right) ; \text { labor cost of } \\
\$ 0.056 / \mathrm{kg} ; \text { general works } \\
\$ 0.029 / \mathrm{kg} \text { including } \\
\text { maintenance, supervision, } \\
\text { administration, property taxes, } \\
\text { and insurance. CAPEX not } \\
\text { included. } \\
\text { w/o co-product valuation }\end{array}$ & $\begin{array}{c}\text { cost of } \\
\text { biodiesel } \$ 0.6 / \mathrm{L} \text { compared } \\
\text { with glucose-based } \\
\text { biodiesel } \$ 3.79 / \mathrm{L}\end{array}$ & [70] \\
\hline $\begin{array}{l}\text { Molasses from } \\
\text { sugar cane } \\
\text { processing }\end{array}$ & $\begin{array}{l}\text { Scale-up simulation on } \\
\text { SuperPro Designer } \\
\text { Auxenochlorella } \\
\text { protothecoides } \\
\text { (50\% lipid content; lipid } \\
0.25 \text { g/g yield) } \\
\text { Product: } \\
\text { Biodiesel and animal feed }\end{array}$ & $\begin{array}{c}\text { Lipid productivity } \\
\text { 8.2 } \mathrm{gL}^{-1} \mathrm{~d}^{-1}, 330 \text { working } \\
\text { days, } 10 \mathrm{ML} \text { bioreactors } \\
\text { CAPEX } 130 \mathrm{M} \$-160 \mathrm{M} \$ \\
\text { (function of equipment cost } \\
\text { covering equipment } \\
\text { Installation, pipping, electrical, } \\
\text { buildings, design and } \\
\text { engineering, Contractor's fee } \\
\text { and contingency) } \\
\text { OPEX } 50-60 \mathrm{M} \$ / \text { year } \\
\text { including } \\
\text { materials costs }+ \text { utilities costs } \\
\text { (\$ } 0.058 / \mathrm{kWh)} \\
+ \text { waste treatment costs }(\$ 1.5 \times \\
10^{-3} \mathrm{~kg}-1 \text { ) }+ \text { labor costs } \\
(\$ 11.50 \text { per work hour) }+ \\
\text { facility related costs } \\
30-y e a r \text { net present value } \\
(\mathrm{NPV}) \text { and internal rate of } \\
\text { return (IRR) Co-product } \\
\text { animal feed ( } \$ 0.45 / \mathrm{kg})\end{array}$ & $\begin{array}{c}\text { Biodiesel price range } \\
\text { Minimum } 2.6-3.0 \$ / \text { liter } \\
\text { for IRR } 12 \%\end{array}$ & {$[71]$} \\
\hline Food waste & $\begin{array}{l}\text { Simulation of process } \\
\text { scale-up } \\
56.3 \mathrm{t} \text { of wet food waste } \\
\text { per day } \\
7.14 \mathrm{t} \text { dried biomass } \\
\text { per day } \\
\text { Chlorella pyrenoidosa } \\
\text { to food and feed }\end{array}$ & $\begin{array}{c}300 \text { working days/year } \\
\text { CAPEX (equipment) } \\
3.3 \mathrm{M} € \\
\text { OPEX (materials, utilities, } \\
\text { labor } 8 € / \mathrm{h} \text { ) } 31.9 \mathrm{k} € / \text { day } \\
\text { Dry biomass revenue } \\
36 \mathrm{k} € / \text { ton }\end{array}$ & $\begin{array}{c}20 \text { years NPV w / 5\% } \\
\text { discount rate } \\
948 \mathrm{M} € \\
\text { In comparison with } \\
\text { autotrophic microalgae for } \\
\text { food/feed applications, } \\
\text { heterotrophic microalgae } \\
\text { cultvation operational cost } \\
\text { is up to } 50 \% \text { lower }\end{array}$ & {$[72]$} \\
\hline $\begin{array}{c}\text { Agroindustrial } \\
\text { wastewater (poultry } \\
\text { and swine } \\
\text { slaughterhouse } \\
\text { wastewater) }\end{array}$ & $\begin{array}{c}\text { Up-scale wastewater flow } \\
\text { rate } 16,000 \mathrm{~m}^{3} / \text { day from } \\
\text { bench-scale facility data } \\
\text { Phormidium }\end{array}$ & $\begin{array}{c}\text { Working } 24 \mathrm{~h} / \mathrm{d} \text { and } \\
336 \text { days/year } \\
\text { CAPEX } 71 \mathrm{M} \$ \text { (equipment, } \\
\text { installation, deployment, } \\
\text { instrumentation, piping) } \\
\text { OPEX } 14 \mathrm{M} \$ \text { /year (raw } \\
\text { materials } \\
\text { and supplies, utilities, labor } \\
\text { costs }(\$ 8.50 / \mathrm{h}), \text { supervision, } \\
\text { payroll charges, maintenance, } \\
\text { operating supplies, general } \\
\text { plant overheads, tax, and } \\
\text { contingency) }\end{array}$ & $\begin{array}{c}\text { 10-year lifetime facility } \\
\$ 2.66 / \mathrm{m}^{3}\left(\$ 0.70 / \mathrm{m}^{3}\right. \\
\text { considering only } \\
\text { operational costs) } \\
\text { Potential revenue dry } \\
\text { biomass production cost } \$ \\
0.03 / \mathrm{kg} \text { (much lower than } \\
\text { conventional heterotephic } \\
\text { fermenters and autotrophic } \\
\text { photobioreactors, and } \\
\text { below theoretical target of } \\
\quad 0.55 \$ / \mathrm{kg}) \\
\text { Return on investment in } \\
\text { the first year of operation }\end{array}$ & [73] \\
\hline
\end{tabular}


The research presented in Table 3 is supported by bench-scale experiments, scaling-up. Therefore, the scale limitations of these economic estimates emphasize the importance of field data coming from pilot plants of suitable size to finally reach an industrial scale. Nevertheless, these exploratory results showed that heterotrophic microalgae have the potential to be used in both food waste and wastewater streams. The products may be food, feed, or biodiesel, or simply clean water, as already mentioned (Figure 1). What is noticeable is that, even with lower-cost carbon sources and accounting for the CAPEX and OPEX costs, the minimum biodiesel cost is still not competitive with traditional biodiesel from 1st generation plants (Figure 3).

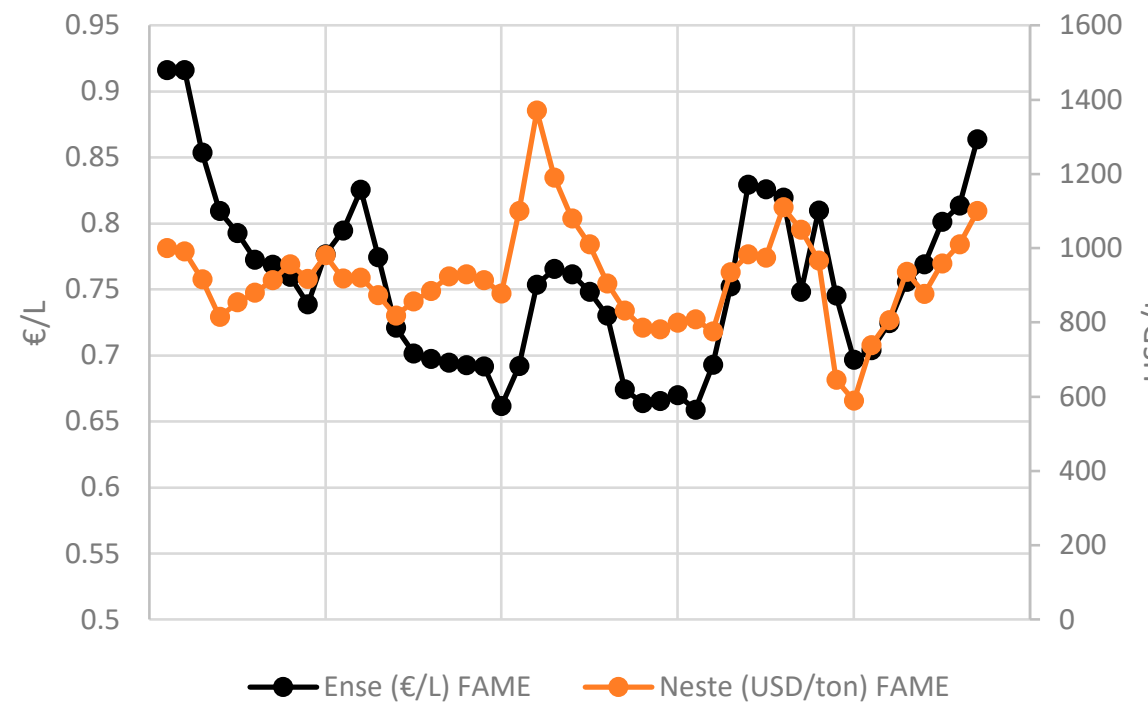

Figure 3. Market price of biodiesel (source: Ense and Neste [74]). Monthly prices since January 2017 until December 2020.

The market prices of biodiesel taken from Neste company (in \$/ton) and assuming a biodiesel density of $890 \mathrm{~kg} / \mathrm{m}^{3}$ would range within $0.45-1.25 \$ / \mathrm{L}$.

The Renewable Energy Directive (2018/2001), together with the waste directive 2008/98/EC (on waste destination hierarchy), could be a game changer in the thirdgeneration market from waste feedstocks. Advanced biofuels are defined as liquid or gaseous biofuels made from materials listed in Part A of the REDII Annex. They have a specific sub-target starting at $0.2 \%$ in 2022 , at least $1 \%$ in 2025 , and increasing to at least $3.5 \%$ in 2030 . In addition, process optimizations such as nutrient and media recycling (lowering materials input operational costs) were never considered in the marketed studies presented in Table 3, but are being evaluated by others [51].

Typical wastewater treatment costs for agro-industrial wastes range between 1.06 and $2.58 \$ / \mathrm{m}^{3}$, covering only operational costs $[75,76]$. The system developed with a heterotrophic bioreactor replacing typical secondary and tertiary treatments presented in Table 3 showed the potential usefulness and role of heterotrophic microalgae in this context.

One of the reviewed studies [77] focused on protein concentrate for food and feed (protein powder). The study does not perform a TEA but points out directions of cost savings because it estimates the $\mathrm{CO}_{2}$ eq emissions (directly related to utilities, heat, electricity, and material carbon sources, and others) of three microalgae species and autotrophic and heterotrophic conditions. The latter achieved the lower impacts (for heterotrophic fermenter cultivation of $C$. vulgaris with glycerol as a carbon source and C. pyrenoidosa with food waste as a carbon source, less than $3-14.7 \mathrm{~kg} \mathrm{CO} 2 \mathrm{eq} / \mathrm{kg}$ protein) and was considered better than most traditional food and feed protein sources (egg concentrate, $23.4 \mathrm{~kg}$ $\mathrm{CO}_{2} \mathrm{eq} / \mathrm{kg}$ protein; spirulina, 78-196 $\mathrm{kg} \mathrm{CO} 2 \mathrm{eq} / \mathrm{kg}$ protein). 


\section{Conclusions}

Heterotrophic microalgae show many advantages over autotrophic microalgae to treat food wastes and municipal/domestic wastewater, as the former has the ability to grow on wastes with high COD loads, simultaneously producing microalgal biomass, biofuels, and high value-added products such as lipids, PUFA, and carotenoids, with different commercial applications.

In addition, heterotrophic growth is non-dependent on the light season and climate, being able to grow at latitudes far from the Equator, contrarily to the autotrophic microalgae.

The main disadvantages are the need for media sterilization, the need for an organic carbon source, and the biogenic release of $\mathrm{CO}_{2}$. These drawbacks can be overcome if high value-added products are produced and if symbiotic heterotrophic-autotrophic microalgae systems are used when treating wastes.

Coupling waste management with concomitant heterotrophic microalgae production may reduce the overall waste treatment process costs, with simultaneous environmental benefits, as this strategy is based on circular economy principles.

However, further research is needed to improve heterotrophic microalgal biomass and high value-added product productivities when using wastes as substrates. The literature review recognizes the need for field data from pilot plants of suitable size to finally reach an industrial scale.

The role of heterotrophic microalgae in treating food waste and wastewater streams is being explored, but pilot scale data are needed to reduce TEA uncertainty at a future industrial level.

Up-scales based on bench-scale experiments project heterotrophic microalgae as competitive and commercially attractive. The target cost to produce $1 \mathrm{~kg}$ dry microalgae should be $0.55 \$$ to compensate for downstream processing into biofuels and bioproducts.

Author Contributions: T.L.d.S. coordinated the manuscript preparation; T.L.d.S., P.M., C.S. and A.R. wrote parts of the manuscript; T.L.d.S., P.M., A.R. and C.S. focus on the economic review. All authors have read and agreed to the published version of the manuscript.

Funding: This work was financed by national funds through FCT-Fundação para a Ciência e a Tecnologia, I.P., within the scope of the project PTDC/EAM-AMB/30169/2017. and also by Grant number UIDB/50019/2021-Instituto Dom Luiz.

Institutional Review Board Statement: Not applicable.

Informed Consent Statement: Not applicable.

Data Availability Statement: Not applicable.

Acknowledgments: The authors thank the Biomass and Bioenergy Research Infrastructure (BBRI)LISBOA-01-0145-FEDER-022059, which is supported by Operational Programme for Competitiveness and Internationalization (PORTUGAL2020), by Lisbon Portugal Regional Operational Programme (Lisboa 2020) and by North Portugal Regional Operational Programme (Norte 2020) under the Portugal 2020 Partnership Agreement, through the European Regional Development Fund (ERDF).

Conflicts of Interest: The authors declare that they have no conflict of interest.

\section{References}

1. Waste Collection Systems Assessed and Good Practices Identified. Available online: https://www.collectors2020.eu/ (accessed on 19 April 2021).

2. Gray, N.F. Biology of Wastewater Treatment, 2nd ed.; Imperial College Press: London, UK, 2004; pp. 1-936.

3. Grady, L.; Daigger, G.; Love, N.; Filipe, C. Biological Wastewater Treatment, 3rd ed.; CRC Press: Abingdon, UK, 2011 ; pp. 1-1395.

4. UN-Water Annual Report 2015. Available online: www.unwater.org (accessed on 19 April 2021).

5. Lopes da Silva, T.; Moniz, P.; Silva, C.; Reis, A. The Dark Side of Microalgae Biotechnology: A Heterotrophic Biorefinery Platform Directed to omega-3 Rich Lipid Production. Microorganisms 2019, 7, 670. [CrossRef] [PubMed]

6. Wang, H.T.; Yang, Y.; Keller, A.A.; Li, X.; Feng, S.J.; Dong, Y.N.; Li, F.T. Comparative analysis of energy intensity and carbon emissions in wastewater treatment in USA, Germany, China and South Africa. Appl. Energy 2016, 148, 873-881. [CrossRef] 
7. Mohsenpour, S.F.; Hennige, S.; Willoughby, N.; Adeloye, A.; Gutierrez, T. Integrating micro-algae into wastewater treatment: A review. Sci. Total Environ. 2021, 752, 1-25. [CrossRef]

8. Mehariya, S.; Goswami, R.K.; Karthikeysan, O.P.; Verma, P. Microalgae for high-value products: A way towards green nutraceutical and pharmaceutical compounds. Chemosphere 2021, 280, 1-23. [CrossRef] [PubMed]

9. Mehariya, S.; Goswami, R.K.; Verma, P.; Lavecchia, R.; Zuorro, A. Integrated Approach for Wastewater Treatment and Biofuel Production in Microalgae Biorefineries. Energies 2021, 14, 2282. [CrossRef]

10. Goswami, R.K.; Mehariya, S.; Karthikeyan, O.P.; Verma, P. Advanced microalgae-based renewable biohydrogen production systems: A review. Bioresour. Technol. 2020, 320, 1-15.

11. Goswami, R.K.; Mehariya, S.; Verma, P.; Lavecchia, R.; Zuorro, A. Microalgae-based biorefineries for sustainable resource recovery from wastewater. J. Water Process. Eng. 2021, 40, 1447-1463. [CrossRef]

12. Bhatia, S.K.; Mehariya, S.; Bhatia, R.K.; Kumar, M.; Pugazhendhi, A.; Awasthi, M.K.; Atabani, A.E.; Kumar, G.; Kim, W.; Seo, S.O.; et al. Wastewater based microalgal biorefinery for bioenergy production. Prog. Chall. Sci. Total Environ. 2021, 751, 141599. [CrossRef] [PubMed]

13. Perez-Garcia, O.; Escalante, F.M.E.; de-Bashan, L.E.; Bashan, Y. Heterotrophic cultures of microalgae: Metabolism and potential products. Water Res. 2011, 45, 11-36. [CrossRef]

14. Girard, J.M.; Tremblay, R.; Faucheux, N.; Heitz, M.; Deschenes, J.S. Phycoremediation of cheese whey permeate using directed commensalism between Scenedesmus obliquus and Chlorella protothecoides. Algal Res. 2017, 22, 122-126. [CrossRef]

15. Shen, L.; Ndayambaje, J.D.; Murwanashyaka, T.; Cui, W.Q.; Manirafasha, E.; Chen, C.X.; Wang, Y.P.; Lu, Y.H. Assessment upon heterotrophic microalgae screened from wastewater microbiota for concurrent pollutants removal and biofuel production. Bioresour. Technol. 2017, 245, 386-393. [CrossRef]

16. Abdel-Raouf, N.; Al-Homaidan, A.A.; Ibraheem, I.B.M. Microalgae and wastewater treatment. Saudi J. Biol. Sci. 2012, 19, 257-275. [CrossRef] [PubMed]

17. Quijano, G.; Arcila, J.S.; Buitron, G. Microalgal-bacterial aggregates: Applications and perspectives for wastewater treatment. Biotechnol. Adv. 2017, 35, 772-781. [CrossRef]

18. Debowski, M.; Zielinski, M.; Kazimierowicz, J.; Kujawska, N.; Talbierz, S. Microalgae Cultivation Technologies as an Opportunity for Bioenergetic System Development-Advantages and Limitations. Sustainability 2020, 12, 9980. [CrossRef]

19. Perez-Garcia, O.; Bashan, Y.; Puente, M.E. Organic Carbon Supplementation of Sterilized Municipal Wastewater Is Essential for Heterotrophic Growth and Removing Ammonium by the Microalga Chlorella Vulgaris. J. Phycol. 2011, 47, 190-199. [CrossRef] [PubMed]

20. Morales-Sanchez, D.; Martinez-Rodriguez, O.A.; Martinez, A. Heterotrophic cultivation of microalgae: Production of metabolites of commercial interest. J. Chem. Technol. Biotechnol. 2017, 92, 925-936. [CrossRef]

21. Ende, S.S.W.; Noke, A. Heterotrophic microalgae production on food waste and by-products. J. Appl. Phycol. 2019, 31, 1565-1571. [CrossRef]

22. Xu, H.; Miao, X.; Wu, Q. High quality biodiesel production from a microalga Chlorella protothecoides by heterotrophic growth in fermenters. J. Biotechnol. 2006, 126, 499-507. [CrossRef]

23. Scaife, M.A.; Merkx-Jacques, A.; Woodhall, D.L.; Armnta, R.E. Algal biofuels in Canada: Status and potential. Renew. Sustain. Energy Rev. 2015, 44, 620-642. [CrossRef]

24. Chen, Y.H.; Walker, T.H. Fed-batch fermentation and supercritical fluid extraction of heterotrophic microalgal Chlorella protothecoides lipids. Bioresour. Technol. 2012, 114, 512-517. [CrossRef]

25. Taborda, T.; Moniz, P.; Reis, A.; da Silva, T.L. Evaluating low-cost substrates for Crypthecodinium cohnii lipids and DHA production, by flow cytometry. J. Appl. Phycol. 2021, 33, 263-274. [CrossRef]

26. Mendes, A.; Guerra, P.; Madeira, V.; Ruano, F.; da Silva, T.L.; Reis, A. Study of docosahexaenoic acid production by the heterotrophic microalga Crypthecodinium cohnii CCMP 316 using carob pulp as a promising carbon source. World J. Microbiol. Biotechnol. 2007, 23, 1209-1215. [CrossRef]

27. De Swaaf, M.E.; Pronk, J.T.; Sijtsma, L. Fed-batch cultivation of the docosahexaenoic-acid-producing marine alga Crypthecodinium cohnii on ethanol. Appl. Microbiol. Biotechnol. 2003, 61, 40-43. [CrossRef] [PubMed]

28. Ratledge, C.; Kanagachandran, K.; Anderson, A.J.; Grantham, D.J.; Stephenson, J.C. Production of docosahexaenoic acid by Crypthecodinium cohnii grown in a $\mathrm{pH}$-auxostat culture with acetic acid as principal carbon source. Lipids 2001, 36, 1241-1246. [CrossRef] [PubMed]

29. Sabeela Beevi, U.; Sukumaran, R.K. Cultivation of the fresh water microalga Chlorococcum sp. RAP13 in sea water for producing oil suitable for biodiesel. J. Appl. Phycol. 2015, 27, 141-147. [CrossRef]

30. Isleten-Hosoglu, M.; Elibol, M. Improvement of medium composition and cultivation conditions for growth and lipid production by Crypthecodinium cohnii. Rom. Biotechnol. Lett. 2017, 22, 13086-13095.

31. Yazdani, S.S.; Gonzalez, R. Anaerobic fermentation of glycerol: A path to economic viability for the biofuels industry. Curr. Opin. Biotechnol. 2007, 18, 213-219. [CrossRef]

32. Samul, D.; Leja, K.; Grajek, W. Impurities of crude glycerol and their effect on metabolite production. Ann. Microbiol. 2014, 64, 891-898. [CrossRef]

33. Zhang, T.Y.; Wu, Y.H.; Zhuang, L.L.; Wang, X.X.; Hu, H.Y. Screening heterotrophic microalgal strains by using the Biolog method for biofuel production from organic wastewater. Algal Res. 2014, 6, 175-179. 
34. Gaurav, K.; Srivastava, R.; Sharma, J.G.; Singh, R.; Singh, V. Molasses-based growth and lipid production by Chlorella pyrenoidosa: A potential feedstock for biodiesel. Int. J. Green Energy 2016, 13, 320-327. [CrossRef]

35. Guldhe, A.; Singh, P.; Kumari, S.; Rawat, I.; Permaul, K.; Bux, F. Biodiesel synthesis from microalgae using immobilized Aspergillus niger whole cell lipase biocatalyst. Renew. Energy 2016, 85, 1002-1010. [CrossRef]

36. Hena, S.; Abida, N.; Tabassum, S. Screening of facultative strains of high lipid producing microalgae for treating surfactant mediated municipal wastewater. Res. Adv. 2015, 5, 98805-98813. [CrossRef]

37. Sloth, J.K.; Jensen, H.C.; Pleissner, D.; Eriksen, N.T. Growth and phycocyanin synthesis in the heterotrophic microalga Galdieria sulphuraria on substrates made of food waste from restaurants and bakeries. Bioresour. Technol. 2017, 238, 296-305. [CrossRef]

38. Mendes, A.; Lopes da Silva, T.; Reis, A. DHA concentration and purification from the marine heterotrophic microalga Crypthecodinium cohnii CCMP 316 by winterization and urea complexation. Food Technol. Biotechnol. 2007, 45, 38-44.

39. Chi, Z.Y.; Hu, B.; Liu, Y.; Frear, C.; Wen, Z.Y.; Chen, S.L. Production of omega-3 polyunsaturated fatty acids from cull potato using an algae culture process. Appl. Biochem. Biotechnol. 2007, 137, 805-815. [PubMed]

40. Devi, M.P.; Subhash, G.V.; Mohan, S.V. Heterotrophic cultivation of mixed microalgae for lipid accumulation and wastewater treatment during sequential growth and starvation phases: Effect of nutrient supplementation. Renew. Energy 2012, 43, 276-283. [CrossRef]

41. Zheng, H.L.; Gao, Z.; Yin, F.W.; Ji, X.J.; Huang, H. Lipid production of Chlorella vulgaris from lipid-extracted microalgal biomass residues through two-step enzymatic hydrolysis. Bioresour. Technol. 2012, 117, 1-6. [CrossRef]

42. Pleissner, D.; Lam, W.C.; Sun, Z.; Lin, C.S.K. Food waste as nutrient source in heterotrophic microalgae cultivation. Bioresour. Technol. 2013, 137, 139-146. [CrossRef] [PubMed]

43. Zhang, T.Y.; Wu, Y.H.; Zhu, S.F.; Li, F.M.; Hu, H.Y. Isolation and heterotrophic cultivation of mixotrophic microalgae strains for domestic wastewater treatment and lipid production under dark condition. Bioresour. Technol. 2013, 149, 586-589. [CrossRef] [PubMed]

44. Gong, Y.; Liu, J.; Jiang, M.; Liang, Z.; Jin, H.; Hu, X.; Wan, X.; Hu, C. Improvement of Omega-3 Docosahexaenoic Acid Production by Marine Dinoflagellate Crypthecodinium cohnii Using Rapeseed Meal Hydrolysate and Waste Molasses as Feedstock. PLoS ONE 2015, 10, 1-18. [CrossRef]

45. Nguyen, H.C.; Su, C.H.; Yu, Y.K.; Huong, D.T.M. Sugarcane bagasse as a novel carbon source for heterotrophic cultivation of oleaginous microalga Schizochytrium sp. Ind. Crop. Prod. 2018, 121, 99-105. [CrossRef]

46. Almeida, M.C.; Butler, D.; Friedler, E. At-source domestic wastewater quality. Urban Water J. 1999, 1, 49-55. [CrossRef]

47. Sajadian, S.F.; Morowvat, M.H.; Ghasemi, Y. Investigation of autotrophic, heterotrophic, and mixotrophic modes of cultivation on lipid and biomass production in Chlorella Vulgaris. Natl. J. Physiol. Pharm. Pharmacol. 2018, 8, 594-599. [CrossRef]

48. Zhang, T.-Y.; Wu, Y.-H.; Wang, J.-H.; Wang, X.-X.; Victor, M.D.-E.; Dao, G.-H.; Tong, X.; Hu, H.-Y. Heterotrophic cultivation of microalgae in straw lignocellulose hydrolysate for production of high-value biomass rich in polyunsaturated fatty acids (PUFA). Chem. Eng. J. 2019, 367, 37-44. [CrossRef]

49. Couto, R.M.; Simões, P.C.; Reis, A.; Da Silva, T.L.; Martins, V.H.; Sánchez-Vicente, Y. Supercritical fluid extraction of lipids from the heterotrophic microalga Crypthecodinium cohnii. Eng. Life Sci. 2010, 10, 158-164.

50. Ward, O.P.; Singh, A. Omega-3/6 fatty acids: Alternative sources of production. Process Biochem. 2005, 40, 3627-3652. [CrossRef]

51. Lowrey, J.; Armenta, R.E.; Brooks, M.S. Nutrient and media recycling in heterotrophic microalgae cultures. Appl. Microbiol. Biotechnol. 2016, 100, 1061-1075. [CrossRef]

52. Bohutskyi, P.; Kula, T.; Kessler, B.A.; Hong, Y.; Bouwer, E.J.; Betenbaugh, M.J.; Allnutt, F.C.T. Mixed Trophic State Production Process for Microalgal Biomass with High Lipid Content for Generating Biodiesel and Biogas. Bioenergy Res. 2014, 7, 1174-1185. [CrossRef]

53. Doucha, J.; Lívanský, K. Production of high-density Chlorella culture grown in fermenters. J. Appl. Phycol. 2012, 24, 35-43. [CrossRef]

54. Li, X.; Xu, H.; Wu, Q. Large-scale biodiesel production from microalga Chlorella protothecoides through heterotrophic cultivation in bioreactors. Biotechnol. Bioeng. 2007, 98, 764-771. [CrossRef] [PubMed]

55. Oliver, L.; Dietrich, T.; Marañón, I.; Villarán, M.C.; Barrio, R.J. Producing Omega-3 Polyunsaturated Fatty Acids: A Review of Sustainable Sources and Future Trends for the EPA and DHA Market. Resources 2020, 9, 148. [CrossRef]

56. Eusébio, A.; Moniz, P.; Lopes da Silva, T.; Marques, I.P. Energetic valorization of Chrypthecodinium cohnii lipid production wastes by anaerobic digestion. In Proceedings of the MicroBiotec'19 Congress, Coimbra, Portugal, 5-7 December 2019.

57. Lopes da Silva, T.; Reis, A. Low-Cost Feedstocks for Biofuels and High Value Added Products Production: Using Multi- Parameter Flow Cytometry as a Tool to Enhance the Process Efficiency. In Recent Advances in Analytical Techniques; Atta-ur-Rahman Sibel, A., Ozkan, U.A.E., Eds.; Bentham Science Publishers: Sharjah, United Arab Emirates, 2019; Volume 3, pp. 40-60.

58. Norvill, Z.N.; Shilton, A.; Guieysse, B. Emerging contaminant degradation and removal in algal wastewater treatment ponds: Identifying the research gaps. J. Hazard. Mater. 2016, 313, 291-309. [CrossRef] [PubMed]

59. Hu, W.; Gladue, R.; Hansen, J.; Wojnar, C.; Chalmers, J.J. The sensitivity of the dinoflagellate Crypthecodinium cohnii to transient hydrodynamic forces and cell-bubble interactions. Biotechnol. Prog. 2007, 23, 1355-1362. [CrossRef] [PubMed]

60. Yeung, P.K.; Lam, C.M.; Ma, Z.Y.; Wong, Y.H.; Wong, J.T. Involvement of calcium mobilization from caffeine-sensitive stores in mechanically induced cell cycle arrest in the dinoflagellate Crypthecodinium cohnii. Cell Calcium 2006, 39, 259-274. [CrossRef] [PubMed] 
61. Chen, J.; Wei, D.; Pohnert, G. Rapid Estimation of Astaxanthin and the Carotenoid-to-Chlorophyll Ratio in the Green Microalga Chromochloris zofingiensis Using Flow Cytometry. Mar. Drugs 2017, 15, 231. [CrossRef]

62. Santos, C.A.; Nobre, B.; da Silva, T.L.; Pinheiro, H.M.; Reis, A. Dual-mode cultivation of Chlorella protothecoides applying inter-reactors gas transfer improves microalgae biodiesel production. J. Biotechnol. 2014, 184, 74-83. [CrossRef]

63. Ferro, L. Wastewater Treatment and Biomass Generation by Nordic Microalgae: Growth in Subarctic Climate and Microbial Interactions. Ph.D. Thesis, Umeå University, Umeå, Sweden, 2019. Comprehensive Summary.

64. Yang, H.L.; Lu, C.K.; Chen, S.F.; Chen, Y.M.; Chen, Y.M. Isolation and Characterization of Taiwanese Heterotrophic Microalgae: Screening of Strains for Docosahexaenoic Acid (DHA) Production. J. Mar. Biotechnol. 2010, 12, 173-185. [CrossRef] [PubMed]

65. Behrens, P. Photobioreactors and fermentors: The light and dark side of growing algae. In Algal Culturing Techniques; Andersen, R.A., Ed.; Elsevier Academic Press: Cambridge, MA, USA, 2005; pp. 189-204.

66. Orfield, N.D.; Levine, R.B.; Keoleian, G.A.; Miller, S.A.; Savage, P.E. Growing Algae for Biodiesel on Direct Sunlight or Sugars: A Comparative Life Cycle Assessment. ACS Sustain. Chem. Eng. 2015, 3, 386-395. [CrossRef]

67. Hu, J.J.; Nagarajan, D.; Zhang, Q.G.; Chang, J.S.; Lee, D.J. Heterotrophic cultivation of microalgae for pigment production: A review. Biotechnol. Adv. 2018, 36, 54-67. [CrossRef] [PubMed]

68. Parsons, S.; Abeln, F.; McManus, M.C.; Chuck, C.J. Techno-economic analysis (TEA) of microbial oil production from waste resources as part of a biorefinery concept: Assessment at multiple scales under uncertainty. J. Chem. Technol. Biotechnol. 2019, 94, 701-711. [CrossRef]

69. Fei, Q.; Chang, H.N.; Shang, L.; Choi, J.; Kim, N.; Kang, J. The effect of volatile fatty acids as a sole carbon source on lipid accumulation by Cryptococcus albidus for biodiesel production. Bioresour. Technol. 2011, 102, 2695-2701. [CrossRef] [PubMed]

70. Fei, Q.; Fu, R.; Shang, L.; Brigham, C.J.; Chang, H.N. Lipid production by microalgae Chlorella protothecoides with volatile fatty acids (VFAs) as carbon sources in heterotrophic cultivation and its economic assessment. Bioprocess Biosyst. Eng. 2015, 38, 691-700. [CrossRef]

71. Sano Coelho, R.; Cuellar, M.C.; Franco, T.T.; van der Wielen, L.A.M. Techno-economic assessment of heterotrophic microalgae biodiesel production integrated with a sugarcane bio-refinery. Biofuel Bioprod. Biorefining 2021, 15, 416-429. [CrossRef]

72. Pleissner, D.; Smetana, S. Estimation of the economy of heterotrophic microalgae- and insect-based food waste utilization processes. Waste Manag. 2020, 102, 198-203. [CrossRef] [PubMed]

73. Santos, A.; Roso, G.; Menezes, C.; Queiroz, M.; Zepka, L.; Jacob-Lopes, E. The bioeconomy of microalgal heterotrophic bioreactors applied to agroindustrial wastewater treatment. Desalination Water Treat. 2017, 64, 12-20. [CrossRef]

74. Biodiesel Prices (SME \& FAME). Available online: https://www.neste.com/investors/market-data/biodiesel-prices-sme-fame\# $97 \mathrm{f} 21970$ (accessed on 20 March 2021).

75. Asselin, M.; Drogui, P.; Benmoussa, H.; Blais, J.F. Effectiveness of electrocoagulation process in removing organic compounds from slaughterhouse wastewater using monopolar and bipolar electrolytic cells. Chemosphere 2008, 72, 1727-1733. [CrossRef]

76. Cristóvão, R.O.; Botelho, C.M.; Martins, R.J.E.; Loureiro, J.M.; Boaventura, R.A.R. Fish canning industry wastewater treatment for water reuse-A case study. J. Clean. Prod. 2015, 87, 603-612. [CrossRef]

77. Smetana, S.; Sandmann, M.; Rohn, S.; Pleissner, D.; Heinz, V. Autotrophic and heterotrophic microalgae and cyanobacteria cultivation for food and feed: Life cycle assessment. Bioresour. Technol. 2017, 245, 162-170. [CrossRef] 